Review

\title{
The reefer container market and academic research: A review study
}

\author{
Bob Castelein a, d, *, Harry Geerlings ${ }^{\text {a, d, }}$, Ron Van Duin b, c, d \\ a Department of Public Administration and Sociology, Erasmus University Rotterdam, Burg. Oudlaan 50, 3062 PA, Rotterdam, the Netherlands \\ ${ }^{\mathrm{b}}$ Faculty of Technology, Policy, and Management, Delft University of Technology, Jaffalaan 5, 2628 BX, Delft, the Netherlands \\ ${ }^{\mathrm{c}}$ Research Center for Sustainable Port Cities, Rotterdam University of Applied Sciences, Heijplaatstraat 23, 3089 JB, Rotterdam, the Netherlands \\ d Project EURECA (Effective Use of Reefer Containers Through the Port of Rotterdam), Netherlands Organization for Scientific Research (NWO) Project 438- \\ 15-505, the Netherlands
}

\section{A R T I C L E I N F O}

\section{Article history:}

Received 22 November 2019

Received in revised form 22 January 2020

Accepted 18 February 2020

Available online 19 February 2020

Handling Editor: Prof. Jiri Jaromir Klemeš

\section{Keywords:}

Reefer

Reefer container

Container transport

Cold chain

\begin{abstract}
A B S T R A C T
The refrigerated (or 'reefer') container market grows rapidly. Researchers and sector stakeholders increasingly realize that this container market segment has its distinct dynamics and demands. This article provides a comprehensive overview of the reefer container sector, its most important characteristics and trends, and a systematic review of the academic literature on reefer containers and logistics. First the authors outline the characteristics, composition, and development of the reefer container market, showing its growth through modal shift (from conventional reefer ships and airfreight) and differentiation into new cargo markets and niche services. Secondly the authors outline reefer chains in terms of their relevant stages, stakeholders, and processes. Data on insurance claims shows that cold chain failure and cargo loss not only occur due to technical failures, but just as often due to organizational errors - especially due to hold-up risk at container transfer points. Thirdly the authors map the present knowledge on reefer containers and reefer transportation through a systematic literature review. The current body of research on reefer containers consists mostly of highly specialized, technical studies on product characteristics and quality preservation, monitoring and control, refrigeration technology, and temperature management. While technological advances in these fields have largely enabled the containerization of cold logistics chains, the first sections of this paper also highlight that many current pressing issues in reefer transportation are logistical and organizational in nature. Therefore, the authors propose a research agenda addressing these overlooked aspects, including supply chain coordination issues and implications of reefer market developments for port policy.
\end{abstract}

(C) 2020 Elsevier Ltd. All rights reserved.

\section{Contents}

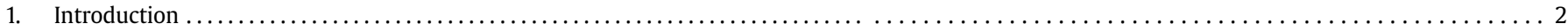

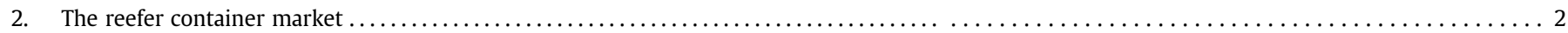

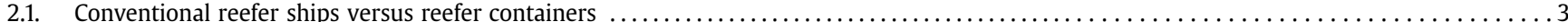

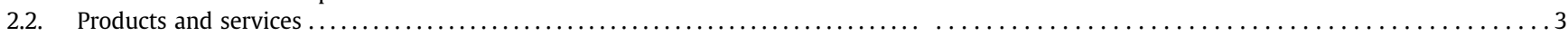

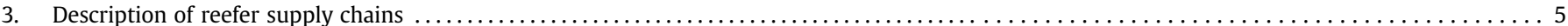

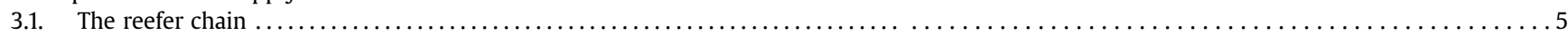

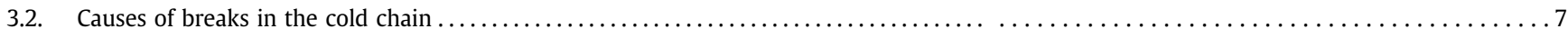

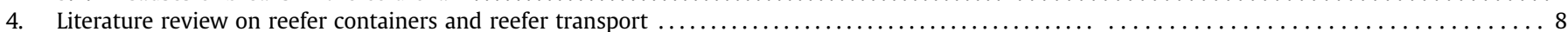

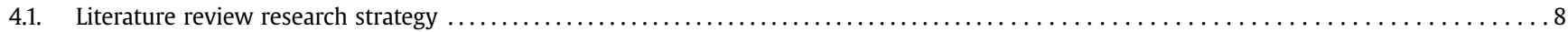

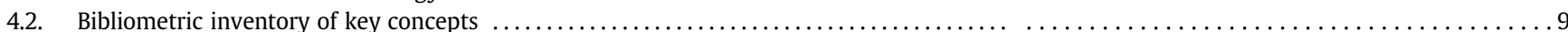

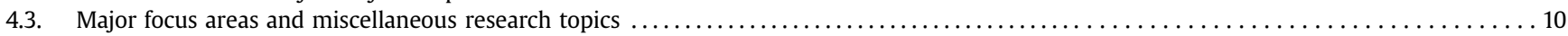

\footnotetext{
* Corresponding author. Department of Public Administration and Sociology, Erasmus University Rotterdam, Burg. Oudlaan 50, 3062 PA, Rotterdam, the Netherlands.

E-mail addresses: castelein@essb.eur.nl (B. Castelein), geerlings@essb.eur.nl (H. Geerlings), j.h.r.van.duin@hr.nl, J.H.R.vanDuin@tudelft.nl (R. Van Duin).
} 


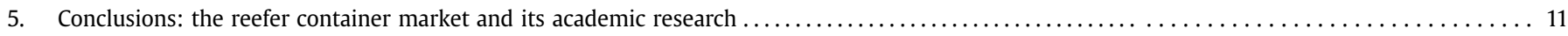

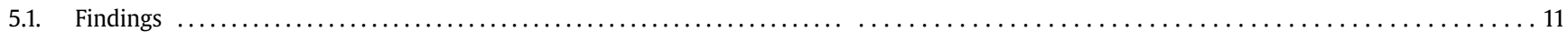

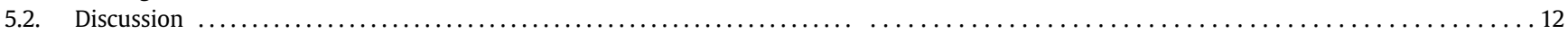

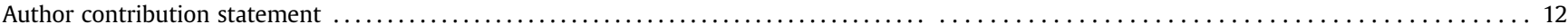

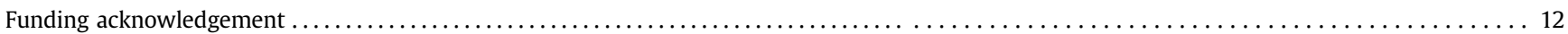

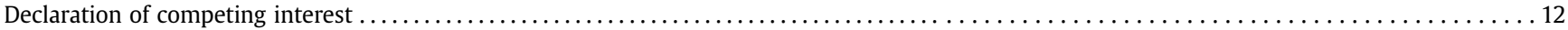

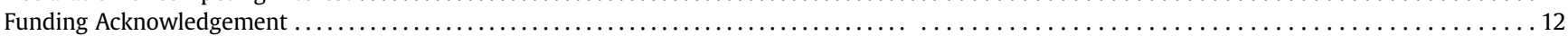

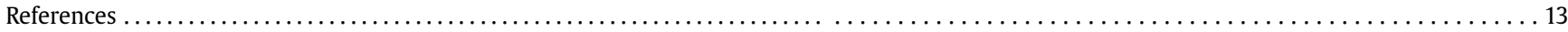

\section{Introduction}

Within the container shipping market, reefer containers are the fastest growing market segment (Drewry Maritime Research, 2016). Reefers - insulated intermodal containers with an integrated refrigeration unit and climate control capabilities - are used for temperature-sensitive products: predominantly food (fruit, vegetables, meat, fish, poultry etc.), but also flowers, plants, pharmaceuticals and numerous minor product categories (e.g. chemicals, film, sensitive equipment, and even some types of clothing). Due to various factors, demand for transport of these products is likely to increase in the future. Globally, due to rising incomes in developing countries, more consumers demand 'exotic' products, such as food and vegetables that cannot be grown in their home market (Darmon and Drewnowski, 2008). On the supply side, more sophisticated preservation techniques and efficient transportation at lower rates make it possible and economically feasible for these products to be transported over longer distances. Furthermore, the gradual replacement of 'bulk' reefer ships by conventional container ships carrying reefer containers has opened the possibility of maritime transport for a wider variety of conditioned cargoes in more fine-grained supply chains (Arduino et al., 2015). To this backdrop, it becomes more and more relevant to address the issues arising from this growing market for containerized conditioned transport.

The food sector is particularly known for its sustainability issues. First of all, this stems from the large amount of product loss. Globally, approximately one-third of all food produced for human consumption is lost or wasted (FAO, 2011), amounting to 1.3 billion tonnes of food lost each year, including losses during transportation. Secondly, transportation of temperature-sensitive produce requires a near-constant supply of energy to cool, freeze, or otherwise condition the goods to prevent product waste during transport (Fitzgerald et al., 2011; Wilmsmeier, 2014). As transportation of food over longer distances to expanding consumer bases increases, also does the energy use along the supply chain.

So far, a coherent body of academic research on the maritime reefer market has not developed yet. A quick scan of publications related to reefer containers and reefer transportation shows that knowledge of this sector is scattered between fields as diverse as refrigeration technology, horticulture and 'Internet of things' (IoT) sensor networks. Moreover, the existing research seems - at a first glance - to be predominantly technically oriented, with logistics and organizational questions receiving relatively little attention. The reefer container market itself, has rarely been the focal topic in academic research. This suggests that issues encompassing the sector in general, and the cold chain in its entirety are not addressed in a comprehensive manner yet. This is understandable, considering the fact that it is only in the last 10-20 years that the reefer container market has shown the spectacular growth to the point where, to policymakers and sector stakeholders, its relevance is extending beyond it simply being a subsector of the container market. It should be noted that a small number of studies have already addressed the reefer market as their focal topic, with attention for overall reefer market developments - primarily growth and modal shift - (Arduino et al., 2015; Thanopoulou, 2012), container contents and differentiation (Rodrigue and Notteboom, 2015), port-related sustainability issues (Castelein et al., 2019b), port policy (Castelein et al., 2019a), logistics and technology (Behdani et al., 2019). However, as of yet, there is little agreement - or even substantive discussion - on what the main questions should be, nor is there a comprehensive understanding of the reefer chain in its entirety and its associated problems. This paper aims to structure existing knowledge of this market, and further facilitate academic and practical discussion on this increasingly relevant topic.

The paper is structured as follows. First, to set the scene, in Section 2 the authors provide an overview of the development and composition of the reefer container market, addressing the longterm trends that drive the development of this market. Section 3 of the paper outlines the cold chain with its relevant stages, stakeholders, and issues. Third, in Section 4, the results of a systematic literature review are presented, including a bibliometric appraisal of the most important sub-streams of research to identify the most important topics addressed - and those overlooked. Based on this, the authors conclude in Section 5, and formulate an agenda with directions for future research.

\section{The reefer container market}

The reefer container market is characterized by the need for continuous temperature control of the container cargoes. Temperature-sensitive goods (food, flowers, chemicals, pharmaceutical products etc.) require near-constant cooling to keep the product at a temperature at which its quality can be preserved for a longer period of time - a so-called 'cold' supply chain, or cold chain for short. For maritime transport of these goods, the integrated intermodal refrigerated (or 'reefer') container has become the standard solution. The name summarizes the most important properties of this container. The integrated refrigeration unit cools down the air that is circulated by two fans. Cold air flows into the cargo hold at the bottom of the container, through the profile of the container floor, and warmer air is fed back into the cooling unit at the top, all the while circulating cooled air through and around the container's contents. The temperature of the warmer air fed back into the reefer unit is monitored in order for the cooling unit to keep the cargo temperature at the desired 'setpoint' temperature. The containers itself are well insulated to prevent the ambient temperature from affecting the cargo, and painted recognizably white to limit the temperature effect of solar radiation. Although the reefer container market has been highlighted as an increasingly important niche within the container shipping market (Guerrero and Rodrigue, 2014; Rodrigue and Notteboom, 2015), academic 
research has so far not addressed its composition or long-term development. The following section outlines these aspects.

\subsection{Conventional reefer ships versus reefer containers}

The development of the reefer container market has been one of growth and modal shift. Until the introduction of the integrated reefer container in the 1970s, seaborne temperature-controlled transport predominantly took place in reefer ships: dedicated ships with cooled cargo holds in which the products are loaded as breakbulk or on pallets (Arduino et al., 2015; Thanopoulou, 2012). These ships - recognizably painted white to maximize the solar radiation reflection (or albedo) of its refrigerated holds - sail from the port of loading to the port of destination in one direct voyage, often at high speeds to limit the reduction in product shelf life at sea. To ensure a continuous cold chain, they are ideally loaded and unloaded (by quay cranes or forklifts at the terminal, or the ship's own cranes in case of a geared reefer ship) from and into cold storage facilities located directly at the quay. Since the introduction in the 1970s of the integrated reefer container as we now know it (Accorsi et al., 2014), and its large-scale uptake by the major container lines in the 1980s and 1990s, the reefer container sector has steadily been eroding the market share of conventional reefer ships and growing strongly (documented by Arduino et al., 2015). The reefer container offers several advantages over conventional reefer ships, namely that the minimum required shipment size is smaller, that the temperature of small consignments can be controlled more accurately, and the intermodal compatibility that allows land-based transportation by train, truck, or inland waterways without opening the container and risking a breach of the cold chain. Moreover, carrying reefers on conventional containerships allow carriers and clients to benefit from economies of scale, bringing down the price of transportation considerably. Due to this shift towards containerization, shipping temperature-sensitive cargoes over long distances became more accessible and more attractive. Combined with global income increases and an increasing demand for 'exotic' products, these dynamics have made reefer shipping the fastest-growing segment in the container shipping market, as described by Drewry, a maritime research and consulting firm (2016).

In 2015, of the estimated total worldwide perishables trade of $191.7 \mathrm{mln}$ tonnes, $105.8 \mathrm{mln}$ tonnes was carried over sea, and the remainder over land or by airfreight. The seaborne perishables trade was split between reefer containers $(84.8 \mathrm{mln}$ tonnes, estimated to be $7.66 \mathrm{mln}$ TEU (Twenty-Foot Equivalent Units - or the capacity of a standard 20-foot intermodal container) and

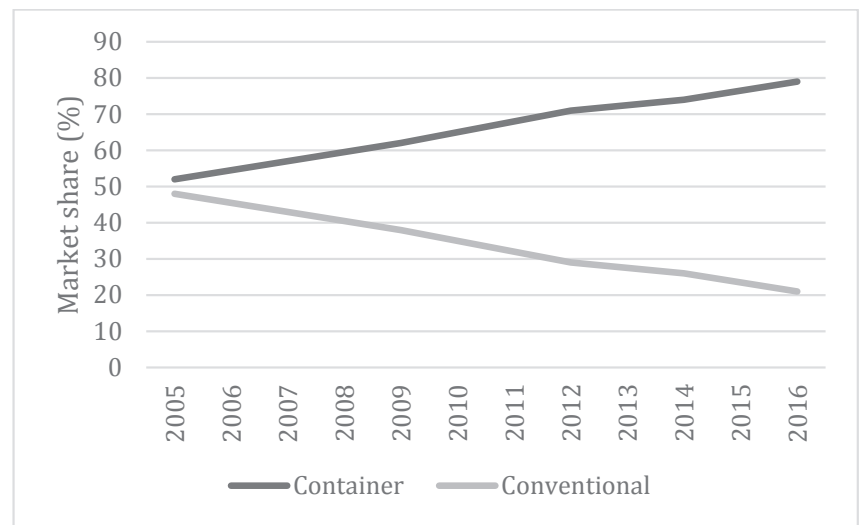

Fig. 1. Modal split of seaborne reefer cargo. Data from Lloyd's List (Nightingale, 2015; Osler, 2019; Tan, 2017). conventional reefer ships ( $21 \mathrm{mln}$ tonnes). The recent development of the relative market shares of the two maritime modes is shown in Fig. 1 below.

Earlier studies that addressed this development (Arduino et al., 2015; Behdani et al., 2018; Rodrigue and Notteboom, 2015; Thanopoulou, 2012) have mostly shown developments in the relative capacity of the two modes, sketching a sharp divergence up to the point where $90 \%$ of all maritime refrigerated transport capacity was containerized (Rodrigue and Notteboom, 2015, p. 218). Fig. 1 shows that this focus on capacity tends to understate the role conventional reefer ships still play. This is due to stark differences in operating models. Whereas an average reefer container makes around five intercontinental trips per year, conventional reefer ships make 7-8 trips per year on average (Van Marle, 2011), with intra-regional services making considerably more (Seatrade, 2019). The difference is due to the higher sailing speed and direct port-toport services of conventional reefer ships, as well as the direct unloading of conventional reefer ships at the quayside, as opposed to reefer containers being moved into ports' hinterlands, being stored in depots, and requiring cleaning, maintenance, and inspection before every new trip.

At the point in time where Fig. 1 starts, container lines had been capturing market share from conventional reefer ship operators for decades, and in 2005, the division of seaborne temperaturecontrolled cargo was approximately $50-50$ between containers and dedicated reefer ships. Since then, the reefer container's dominance has increased steadily to a market share of almost $80 \%$ in 2016. According to research from UNCTAD (2012), Drewry (2016) and Dynamar (2017), the specialized reefer market will stabilize to provide volume on specific trades that still demand conventional services (e.g. ports with underdeveloped infrastructure, seasonal demand peaks around harvests, transloading fish at sea), while further market growth is likely to come from reefer container services.

Nevertheless, hybrid options have also come to the market in the form of conventional reefer ship operators incorporating reefer containers in their business model (Thanopoulou, 2012). This ranges from older conventional reefer ships being retrofitted with container racks and reefer plugs, to operators ordering new build hybrids (with both conventional and container carrying capacity) and fully containerized reefer vessels. An example of this trend is Seatrade, the largest specialized reefer ship operator worldwide with a market share of approximately 30\% (Dynamar, 2017). As of 2019, the average reefer vessel operated by Seatrade Reefer Chartering is approximately 23 years old (built in 1996), whereas the average specialized reefer container vessel is only 6 years old (built in 2013) (Seatrade, 2019). Even with fully containerized vessels, conventional operators still operate on a 'Fast, Direct, Dedicated' model (a term first introduced by Seatrade): fast-sailing ships sailing directly from origin to destination (no multiple ports of call or transshipment), and specializing exclusively in refrigerated transport (Drewry, 2016). This relatively recent development may illustrate the future differentiation between traditional container lines and reefer ship operators, where both offer containerized capacity (preferred by most shippers for the smaller parcel size, flexibility, and intermodal compatibility), but shippers can opt for fast, direct, and dedicated services from specialized operators at a premium.

\subsection{Products and services}

To consider what the current market for seaborne perishables transport looks like, Fig. 2 below shows the total volume of seaborne perishable reefer cargoes (container and conventional), broken down by product category, between 2005 and 2015 . 


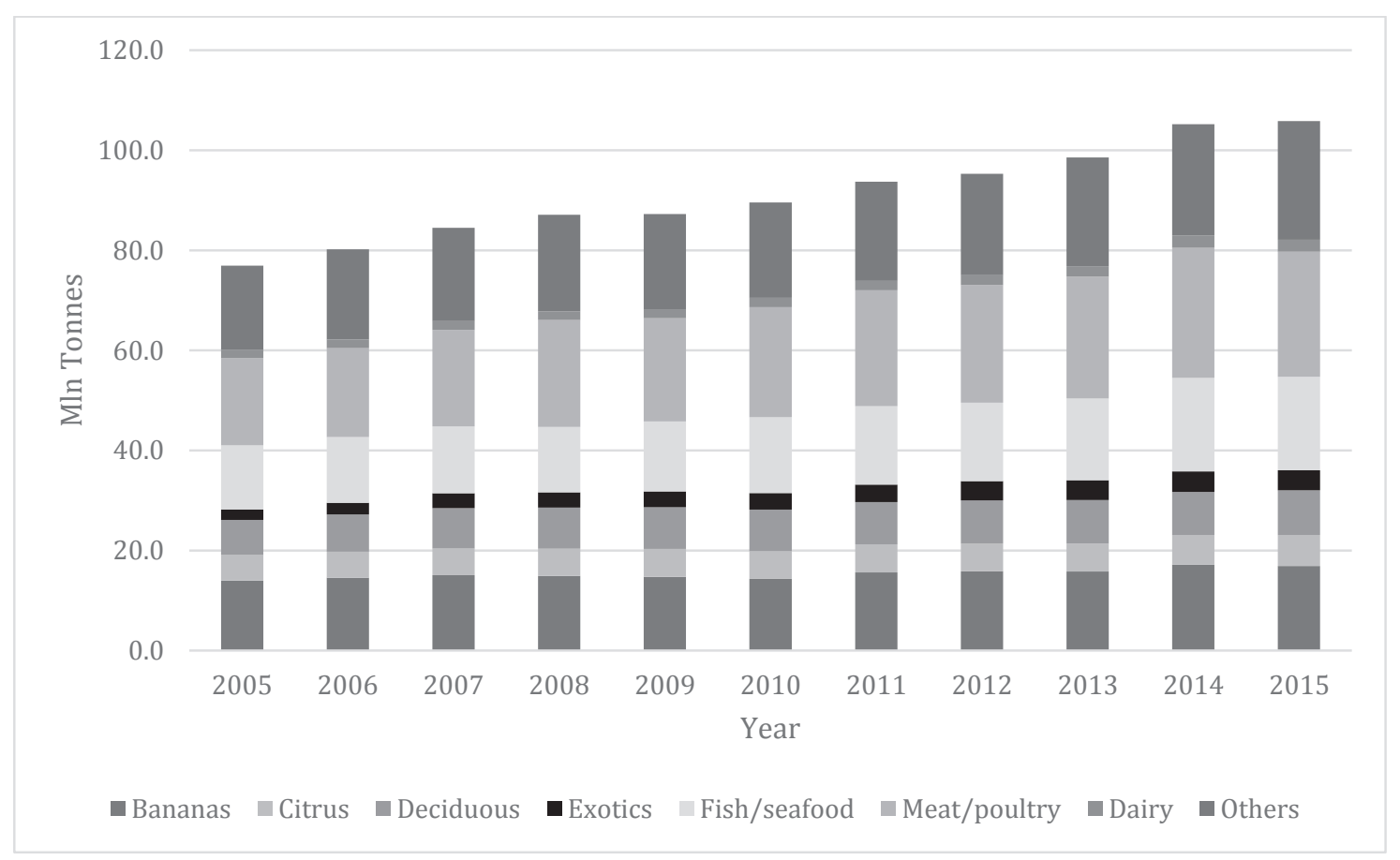

Fig. 2. Seaborne perishable reefer cargoes, volumes by product category, 2005-2015. Data from Drewry (2016).

Fig. 2 serves to give an overview of what the seaborne perishables transport market looks like. Large product categories are bananas, meat and poultry, fish and seafood, and cargoes labeled 'other' (including vegetables, potatoes, and a variety of miscellaneous cargo types, as will be discussed later). Smaller product categories are dairy, and various types of fruit: citrus (oranges, lemons etc.), deciduous (grapes, apples, pears etc.), and exotics (pineapples, kiwi, avocados etc.).

Figs. 1 and 2 illustrate the two main trends occurring in the seaborne reefer market. First, the reefer market has grown steadily (Fig. 2) in nearly all market segments, at an estimated CAGR (Compound Average Growth Rate) in excess of 3\% since 2005 (Drewry, 2016; Dynamar, 2017). Second, the growth has predominantly been in the reefer container sector, relative to a conventional reefer ship sector that has gradually been losing market share (Fig. 1).

While $80 \%$ of this market is transported in containers and $20 \%$ in conventional reefer ships, the containerization rate differs considerably across product categories. Fig. 3 below shows the split of the main seaborne reefer cargoes between specialized reefer vessels and container carriers:

Conventional reefer ships seem to have retained a considerable position in some of the larger product categories such as bananas, fish/seafood, citrus, and exotic fruits. In other segments, in particular dairy and 'other', containerization is the norm. Based on other information available from Drewry (2016), the composition of the containerized reefer market can be described, as shown in Fig. 4 below.

In this data, shown for one year (2015), the category 'other' is broken down into its main separate sub-categories. The most important of these is vegetables, followed by several smaller categories such as pharmaceutical products, potatoes, confectionery, and cut flowers. It should be noted that there is still another category labeled 'other perishable', which is still quite sizable at approximately 400,000 TEU per year.

Another important aspect of the development of the reefer container market is that not only the volume of goods carried in reefer containers per year is growing, but also the variety of goods. In a generally mature container market, further growth is likely to come from the development of new niche markets (Guerrero and Rodrigue, 2014), such as reefer shipping. However, also within the reefer shipping market further differentiation of the cargo market and service offer can be distinguished. In essence, every type of product can be transported in a reefer container at the temperature desired by the shipper, which can fall into one of two categories: frozen (generally kept at a setpoint temperature below $-10{ }^{\circ} \mathrm{C}$ ) or chilled (kept at a setpoint temperature above $-5{ }^{\circ} \mathrm{C}$ ). Frozen cargo makes up approximately 20\% of all reefer cargo, with around $80 \%$ of fish and $45 \%$ of meat being transported frozen as well as most processed potatoes, and smaller shares of fruit and vegetables (Dynamar, 2017). For a wide range of chilled and frozen products, ordinary reefer containers can be used, but increasingly more specialized reefer container technology is introduced for particularly demanding niche markets. Table 1 lists (non-exhaustive) examples of these technologies, their application, and examples of service providers offering it, based on information gathered from industry journals such as Lloyd's List, Port Technology, and Journal of Commerce.

The variety of products transported in reefer containers does not only grow through the introduction of these dedicated containers, but also through product categories being transported in conditioned containers that previously were not. Anecdotal examples include electronics, sneakers (with temperature-sensitive glue), paint, and flowers (still predominantly carried by airfreight).

This last category hints at another driver of growth in the reefer container market. Summarizing, the growing global demand for imported perishables due to rising incomes, as well as a shift of cargo from conventional reefer ships to containers were discussed. A third driver of market growth is a modal shift from air transport to (containerized) maritime transport. A distinct advantage of airfreight over seafreight is the shorter transit time, making it an attractive option for urgent shipments and high-value, temperature-sensitive goods with a very limited shelf life and limited options for extending 


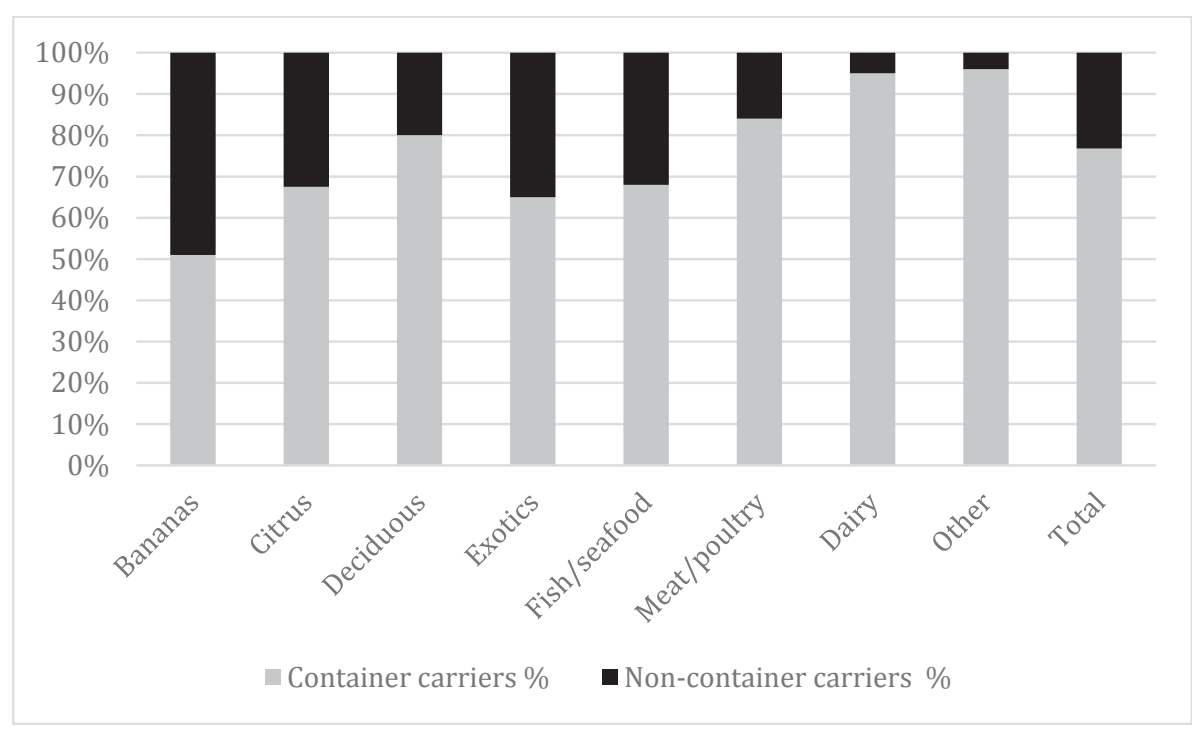

Fig. 3. Modal split of main seaborne reefer cargo categories (year 2015). Data from Drewry (2016).

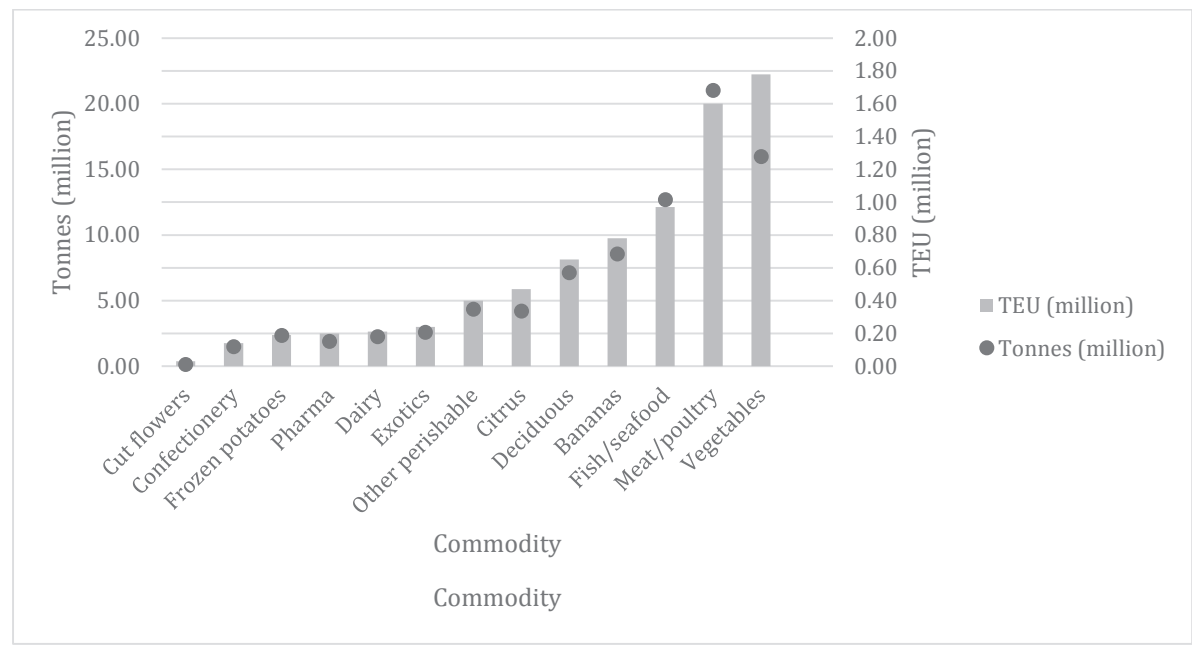

Fig. 4. Reefer container volumes by commodity (year 2015). Data from Drewry (2016).

this. Examples include cut flowers, asparagus, strawberries, raspberries, cherries, some tropical fruits, and certain types of pharmaceutical products. Advances in technologies for product preservation and temperature and climate control of reefer containers (including the Controlled Atmosphere containers shown in Table 1) open up the possibility of maritime transportation for goods that could previously only be flown.

\section{Description of reefer supply chains}

This section describes a generalized overview of the reefer container transport system. Subsequently, in the next section (Section 4), we can make a systematic assessment of the present state of knowledge of this system.

\subsection{The reefer chain}

To achieve an integrated perspective on the reefer chain, we should consider it as part of the 'cold chain' or rather 'cold chains'- i.e. "the equipment, processes and information management used to protect chilled and frozen [cargo, in which] the transport phases (i.e. loading, unloading, handling, and storage) play a fundamental role" (Montanari, 2008). Temperature integrity is an important requirement in the cold chain. Every type of cargo has a temperature range at which it should be kept to maintain product quality (Likar and Jevšnik, 2006; Matthias et al., 2007) (see Hamburg Süd (2010) for a complete overview of temperature requirements per product category). Over the entire course of the supply chain, from production to the consumer, this temperature should be maintained as close as possible to - or at least within a desired bandwidth around - the benchmark temperature. Not all cold chains involve reefer containers; only those that involve goods being produced in one location and transported to another location at a large enough distance and/or at a large enough scale to warrant containerized transport. Moreover, for most goods only part of the cold chain is containerized. In case of containerized transport, the cargo needs to be preserved at the required temperature, so that the reefer container only has to maintain the product temperature, rather than cool it down. 'Hot stuffing' (loading goods into a container while their temperature is far above the desired range) may lead to product quality deterioration, as reefer containers 
Table 1

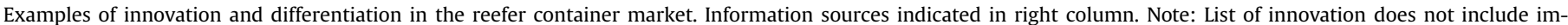
provements to 'standard' integrated reefer container equipment, such as improved insulation, energy efficiency, or reefer unit functioning.

\begin{tabular}{|c|c|c|}
\hline Technology description & Application & Examples of services and operators (non-exhaustive) \\
\hline $\begin{array}{l}\text { Reefers with water tanks inside, include filtration and } \\
\text { oxygen regulation }\end{array}$ & Transport of live lobsters and other live seafood & $\begin{array}{l}\text { CMA CGM AquaViva (Barnard, 2016); Maersk/Aqualife } \\
\text { collaboration (now defunct) (American Journal of } \\
\text { Transport, 2010) }\end{array}$ \\
\hline $\begin{array}{l}\text { Controlled atmosphere: Regulates not only } \\
\text { temperature, but also oxygen and } \mathrm{CO}_{2} \text {, to extend } \\
\text { product shelf life }\end{array}$ & $\begin{array}{l}\text { Transport of sensitive foodstuffs (especially with high } \\
\text { respiration rates), flowers }\end{array}$ & $\begin{array}{l}\text { Hapag Lloyd ExtraFresh Plus (Doe, 2017); Carrier } \\
\text { Transicold Xtendfresh (Sowinski, 2015a); MCI CA } \\
\text { (Wold Cargo News Editorial, 2018) }\end{array}$ \\
\hline $\begin{array}{l}\text { Advanced air cleaning technology, including application } \\
\text { of UV light and ozone }\end{array}$ & Removing ethylene, microbes & $\begin{array}{l}\text { MCI/Primaira Bluezone (Journal of Commerce Staff, } \\
\text { 2014) }\end{array}$ \\
\hline $\begin{array}{l}\text { Liquid cargo solutions: Instead of loading individual } \\
\text { pallets with bottles or bulk containers, liquids can be } \\
\text { pumped into a flexible 'bag' inside the reefer } \\
\text { container }\end{array}$ & Transport of juices, milk, syrups, concentrates, wine etc. & $\begin{array}{l}\text { CMA CGM REEFLEX (American Journal of Transport, } \\
\text { 2018) }\end{array}$ \\
\hline $\begin{array}{l}\text { Reefers that can cool down to extremely low } \\
\text { temperatures }\left(-60^{\circ} \mathrm{C} \text { instead of the usual }-35^{\circ} \mathrm{C}\right) \text {, } \\
\text { some with the option of 'blast' freezing (quicker } \\
\text { cooling process). }\end{array}$ & $\begin{array}{l}\text { Transport of high-value perishables that require } \\
\text { extremely low temperature, such as certain types of fish } \\
\text { and seafood (raw tuna, swordfish sea urchins), vaccines, } \\
\text { and biologics }\end{array}$ & $\begin{array}{l}\text { HMM Ultra-Freeze (Doe, 2018); Klinge Corp. Deep } \\
\text { Freezer Container; Maersk and CMA CGM Super Freezer } \\
\text { (Healey, 2018) }\end{array}$ \\
\hline $\begin{array}{l}\text { Reefer containers with two reefer units, offering a back- } \\
\text { up in case the primary unit malfunctions. Variants } \\
\text { come with integrated diesel-generators to provide } \\
\text { independent power supply }\end{array}$ & $\begin{array}{l}\text { Transport of dangerous goods, and high-value, sensitive } \\
\text { shipments }\end{array}$ & $\begin{array}{l}\text { Klinge Corp. Dual Redundant Refrigeration Unit } \\
\text { (Refrigerated Transporter, 2015) }\end{array}$ \\
\hline $\begin{array}{l}\text { 'Smart' reefers: Reefers with real-time monitoring and } \\
\text { control capabilities. }\end{array}$ & $\begin{array}{l}\text { Can be installed on all reefer containers, allows for: } \\
\text { - Real time monitoring of cargo } \\
\text { - Real time monitoring of reefer unit's functioning } \\
\text { - Asset management for container fleets } \\
\text { - Predictive maintenance } \\
\text { - Temperature changes during voyage (e.g. on-board } \\
\text { ripening, Cold Treatment to meet phytosanitary } \\
\text { requirements) }\end{array}$ & $\begin{array}{l}\text { Currently being rolled out among most major carriers' } \\
\text { reefer fleets. Examples include Maersk Remote } \\
\text { Container Monitoring (RCM) (Sowinski, 2015b), } \\
\text { Tranxens, Loginno (Johnson, 2019) }\end{array}$ \\
\hline
\end{tabular}

typically cannot cool down cargo quickly (Defraeye et al., 2016, 2015b).

In a typical containerized cold chain, this looks as visualized in Fig. 5 below.

First, the cargo is produced (or grown and harvested) somewhere and sometimes processed. From there it is consolidated into a reefer container and transported to a nearby seaport, to be shipped to its destination region on a container vessel. At the port of destination, it is unloaded and transported to a distribution center. Here the cargo is unpacked from the container, and distributed further in smaller parcels to retailers. In the case of food, most product losses due to cold chain breaches occur at the location of production and at the retail and consumption stages of the chain (FAO, 2011), but during the containerized part of the cold chain, temperature integrity is just as important. Although the reefer container is designed to maintain a constant temperature at the required benchmark, this depends on the right conditions of packaging, a secure energy supply, and adequate handling of the container at various transfer points.

Zooming in on the containerized part of the cold chain and the various stakeholders involved produces a stylized picture like the one in Fig. 6 below.

It should first and foremost be noted that this is still just a simplification of the reefer chain. In this case, we assume that the flow of goods is long-distance and warrants maritime transport. Moreover, this figure only reflects the flow of containerized goods in the chain, leaving aside - for this moment - the parties that are involved in financial, legal, informational, and administrative transactions that make these container movements possible.

In this stylized example, the exporting party usually contracts a logistics provider to transport the container from the consolidation center to the port of loading. Through a container terminal, the container is loaded onto a vessel, shipped, and unloaded again at the port of destination. The shipping companies carrying the containers over sea are usually the party that owns the container itself (or leases it on a long-term contract) and rents out the containers (as well as their carrier services) to shippers or their logistics service providers. The shipper (i.e. the party ordering the goods in the container to be shipped) usually contracts a third party logistics service provider (abbreviated to LSP) arrange transportation from the terminal gate (upon release) - either by train over rail, by barge over inland waterways, or by truck over road (or a combination of these modalities, operated by a transportation service provider (or TSP)) - to the distribution center where the container is unpacked and the cargo is further distributed and/or processed. Specific for the reefer chain is that reefers are more complex and maintenanceintensive than standard containers, and that they require a socalled 'pre-trip inspection' (PTI), maintenance, and cleaning of the

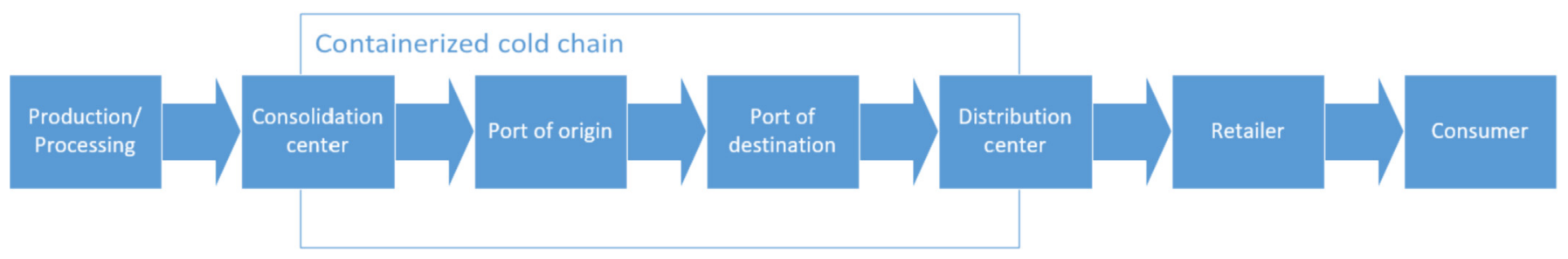

Fig. 5. Stylized overview of the cold chain. Based on the authors' own research, see Section 3.1. 


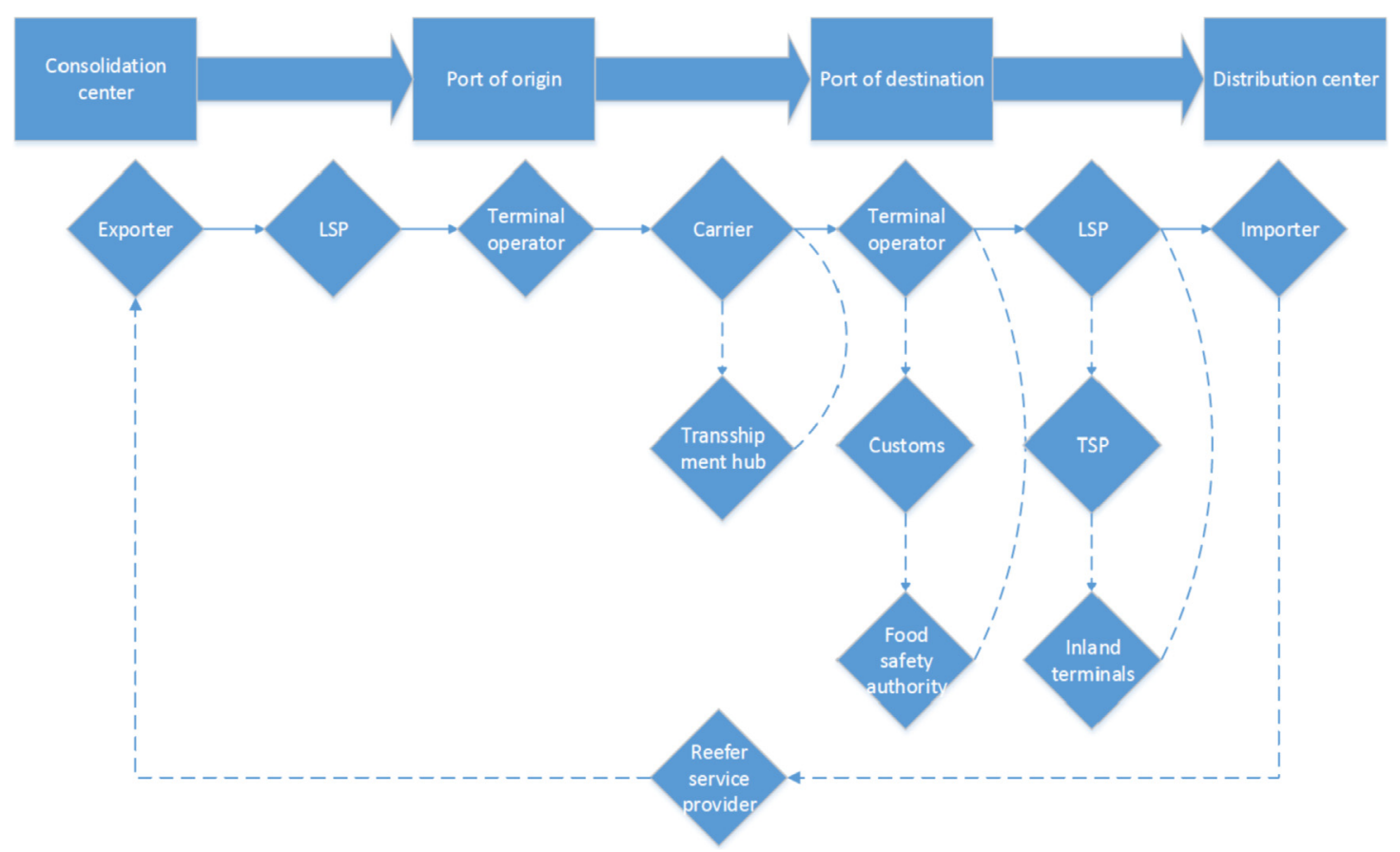

Fig. 6. Stylized overview of the reefer container chain and its logistics actors. Based on the authors' own research, see Section 3.1.

reefer to make sure that the equipment is working properly before being loaded again for its next voyage. Dedicated firms provide these services, either at their own premises or at container depots.

As mentioned before, it is useful to extend our scope beyond the parties that physically handle the container, and look not only at the physical container movements that constitute the reefer chain, but also the administrative transactions and governing entities. Van Oosterhout (2008) distinguishes three layers of stakeholders involved: primarily the logistics layer (where physical goods are moved), secondly the transaction layer (the 'contracting or transaction activities that encompass all commercial relations between parties in the supply chain'), and thirdly the governance layer (predominantly 'inspection and verification activities'). The figures above summarize a stylized cold logistics chain and identify the relevant actors, but three important governance-related actors are not included yet. First, port authorities are involved in maritime reefer transport. A port authority manages a port's infrastructure and acts as port regulator. Port-based companies, such as terminals and possibly shippers and logistics service providers, depend on port authorities for the quality of their shared infrastructure, cluster management, and have to comply with port regulations. Container lines pay port dues set by the port authority, procure services such as tugs and pilotage (sometimes offered by the port authority, sometimes by independent companies) and also have to comply with regulations. Customs organizations are responsible for controlling transnational transport flows, and hence cold chain stakeholders have to comply with customs regulations when importing or exporting their cargo. Moreover, upon arrival in a port, import containers can be selected for scans or checks by customs. In developed importing markets, reefers tend to be selected disproportionately frequently for customs checks, as many types of fruit tend to come from regions known for drug production. A third relevant type of governing organization is food safety authorities, generally in the country of origin as well as the country of destination. Several food safety regulations apply to the cargoes typically transported in reefer containers, enforced by these authorities. Plants or plant-based products - depending on the type of product and/or the countries involved - often require a phytosanitary certificate from the country of origin (in which the exporting country's food safety authority attests to the product not being affected by pests or diseases), and/or a phytosanitary inspection or treatment upon arrival in the country of destination. Analogously, animals or products of animal origin may require veterinary certificates and/or inspections.

This is still an abstraction and simplification of a real-life reefer chain. Here in particular, we assume that the cargo is containerized from shipper to importer (or consignee) or - equivalently - that the shipper is the party that consolidates the container cargo and the consignee is the party that distributes the container cargo. Also importantly, it should be emphasized that there may be multiple logistics service providers involved in the transportation between origin and port and port and destination, in various contractual arrangements (different parties contracted by shipper, or subcontracted by a principal logistics service provider). Moreover, the 'financial group' of actors (Wagenaar, 1992), namely banks and insurance companies, is left out to keep a focus on the containerized logistics part of the supply chain.

\subsection{Causes of breaks in the cold chain}

As discussed above, product quality of reefer cargoes depends on the extent to which a constant temperature can be maintained during their time in transit. As long as a reefer container is undamaged, the unit is working properly, the container is connected to a power source, and the reefer unit settings are appropriate for the cargo inside, product quality should be able to be maintained as long as possible. Prolonged deviation from the required temperature (and possibly Controlled Atmosphere requirements) can cause product quality to deteriorate and ultimately lead to a total loss of the cargo.

Causes of insurance claims can help shed light on reasons why breaks in the cold chain would occur. Research by the North of England P\&I Association (a major marine insurance company) highlights two main reasons for cold chain breaks and claims (2013): 
- Reefer unit (and/or Controlled Atmosphere) malfunction: If detected and repaired in time, this does not necessarily entail cargo loss, but monitoring on ships and terminals may be infrequent, and repairs may not be possible due to lack of expertise or spare parts.

- Excessive time off-power: This may occur due to the container not being plugged in after being moved or transferred from one party to another, or the transfer taking too long.

Two other minor causes include hot stuffing (loading the container with cargo at a temperature far above its required preservation temperature, which the reefer container itself is not able to cool down quickly), and exceeding of the product storage life in transit. The UK P\&I Club has added to this a more extensive list of claim causes (UK P\&I Club, 2017):

- Incorrect settings on container (human error)

- Inappropriate mix of cargo in the container

- Poor cargo quality at loading (old, or otherwise faulty products)

- Late harvest

- Poor packaging

- Cold treatment failure

- Delays

Recommendations to cargo owners include collecting all relevant documentation, ensuring the container's pre-trip inspection (PTI) with report, and installing data loggers on the cargo to monitor temperature and - when necessary - identify moments of deviation.

\section{Literature review on reefer containers and reefer transport}

\subsection{Literature review research strategy}

When evaluating the current state of the academic literature on reefer container transportation, the authors follow as much as possible a systematic literature review approach to ensure transparency and replicability (specifically the commonly accepted Preferred Reporting Items for Systematic Reviews and MetaAnalyses, or PRISMA approach - see Moher et al. (2009).

PRISMA entails a systematic set of steps to find, screen and include studies for the body of research to be examined. This is visualized in the flowchart in Fig. 7 below.

The search for relevant publications was conducted as follows. First the major academic databases Scopus (Elsevier) and Web of Science (Clarivate Analytics, formerly Thomson Reuters) were searched, using the following search terms:

reefer* OR refrigerat* AND container* AND (transport* OR port* OR maritime OR intermodal OR ship* OR terminal* OR cargo)

To obtain all published research related to reefer container transportation, the authors included the main terms 'reefer*' (capturing 'reefer' as well as 'reefers' by using the asterisk), 'refrigerat*' (capturing 'refrigeration', 'refrigerated', and 'refrigerator'), and 'container*' (capturing 'container' as well as 'containers') and included the additional terms in brackets to narrow the selection down to intermodal transport containers. Secondly, the authors consulted experts (i.e. researchers with a considerable publication and citation record on this theme) for further recommendations. This search was conducted in September 2019, and the web-based tool Covidence ("Covidence systematic review software," 2019) was used to keep track of the steps of the systematic review process and all inclusions/exclusions.

After removing duplicates from the search results, 950 studies

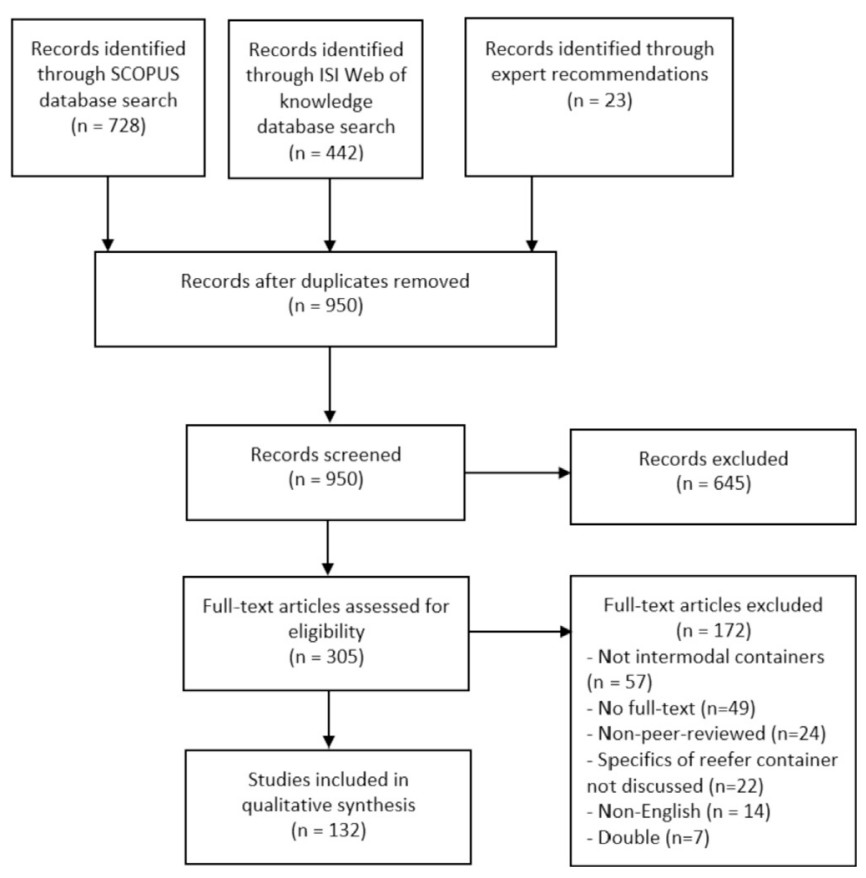

Fig. 7. PRISMA flow diagram of research strategy. Flowchart adapted from Moher et al. (2009), conducted through the Covidence systematic review software ("Covidence systematic review software," 2019).

were screened for relevance (i.e. evaluated based on title, abstract, and source). The criteria for exclusion in this stage were as follows:

- Research not related to intermodal reefer containers (e.g. cooling technology in other applications, types of containers other than intermodal, refrigeration of products in other settings, dry intermodal containers)

- Non-peer-reviewed research (mostly industry publications such as Naval Architect, Journal of Commerce, Containerization International etc.)

- Non-English publications (as publications in French, Portuguese, Korean, or Chinese without a translation could not be read by the authors)

After removing studies meeting these exclusion criteria, of the remaining 305 studies the full-text was read, and 173 studies were excluded, based on the following criteria:

- On closer inspection, the study did not address intermodal reefer containers at all (57 removed), or only superficially (e.g. network models treating a reefer container as a separate class of container, but not considering specific characteristics of the containers, their handling requirements, and cargoes) (22 removed)

- No full text was available for screening, neither from the publisher, research institution, or researcher's personal web pages such as ResearchGate.com and Academia.edu (49 removed)

- On closer inspection, the study was not from a peer-reviewed source (24 removed) or not available in English, despite an English title and abstract $(\mathrm{n}=13)$

- Double studies not filtered out of the search results by Covidence $(n=7)$

Having completed this process yields a selection of 132 studies to be examined. 


\subsection{Bibliometric inventory of key concepts}

The authors first use a bibliometric approach to obtain an overview of the current literature on reefer container logistics, see which topics receive the most attention, and how bodies of research on these various facets of reefer transportation are linked to each other. For this step, the program VOSviewer ${ }^{1}$ is used to visualize as a network the keywords that are used the most in quantitative terms, and in relation to each other. To obtain the most meaningful overview of connections between keywords, authors' keywords of equal meaning but different wording are harmonized. Examples include (phrasing used indicated in bold):

- Air flow vs airflow

- Bananas vs banana (and other plural/singular: container vs containers)

- Cold chain vs cold-chain

- Model vs modeling (ties in with other terms (modeling and control etc.))

- Orange fruit vs orange

- Perishable vs perishable products, perishable food products

- RFID vs Radio Frequency identification

- Sea transport vs sea shipment or sea transportation

Moreover, if studies have a focus on product quality, but only include keywords such as 'quality control' or 'product quality' or 'quality monitoring', the authors took the liberty to include the additional keyword 'quality' to link studies with analogous keywords. In VOSviewer, the authors limit the keywords visualized to those that are included by at least 5 publications in the search results, yielding a total of 39 frequently used keywords. The network structure of these core concepts is visualized in Fig. 8 below.

The VOSviewer program identifies 'clusters' of keywords that are used together particularly often. These clusters represent the major sub-themes within the research on the overarching theme of reefer container transportation. In the case of the literature on this theme, five research clusters can be identified (as color-coded in Fig. 8). The more central concepts appear in the middle of the network and show - accordingly - the most connections to other concepts. Although these central concepts are assigned to only one cluster, the degree of connectedness to other clusters shows where clusters overlap.

Cluster 1 (marked in yellow): The focus of this cluster is on monitoring and control technologies, with specific attention for the possibility of connecting containers to the internet as part of the 'internet of things' (IoT). In a particularly prolific part of the literature, this is called the 'intelligent' or 'smart' container: connected containers, with advanced (remote) monitoring and control capabilities (e.g. Gehrke et al., 2006; Jedermann et al., 2010; Dittmer et al., 2012; Jedermann et al., 2014a,b). An interesting application of this capability would be to make adjustments to logistics processes based on improved knowledge of reefer containers' internal conditions and product quality (e.g. Lutjen et al., 2013; Haass et al., 2015; Lin et al., 2016; Mees et al., 2018).

Cluster 2 (marked in blue): Research within this cluster focuses on understanding the internal conditions of the container in terms of temperature, airflow, and atmosphere composition. Other aspects that are touched upon are product packaging and product quality.

\footnotetext{
${ }^{1}$ VOSviewer is a tool to visualize bibliometric networks (see http://www. vosviewer.com/) that constructs these networks based on co-authorship, cooccurrence of keywords, and citations between papers. See Van Eck and Waltman (2010) for more information.
}

Another major keyword in this cluster, 'CFD', refers to computational fluid dynamics, the predominant method of modeling internal conditions of reefer containers (e.g. Smale et al., 2006; Rodríguez-Bermejo et al., 2007; Jedermann et al., 2013; BadiaMelis et al., 2016; Getahun et al., 2017a,b). With CFD methods appearing in 18 papers, this constitutes a major share of reefer container research, and as such, several papers reviewing research on this approach have been published as well (James et al., 2006; Smale et al., 2006; Xia and Sun, 2002).

Findings from this stream of research have an important practical application in addressing temperature differences within reefer containers. Even in a well-insulated container with a properly functioning cooling unit, temperature distribution is not necessarily uniform, leading to temperature deviations in so-called 'cold' and 'hot spots' which - if persistent - result in product quality differences within the same shipment (Issa and Lang, 2016; Jedermann et al., 2014b, 2013; Jedermann and Lang, 2017). Different ways of loading pallets with cargo into reefer containers can affect airflow and temperature distribution so as to reduce the risk of cold and hot spots (Luchsinger et al., 2018), as well as changes to the way the reefer unit manages cooling and airflow (Defraeye et al., 2016).

Cluster 3 (marked in purple): Overlaps to some extent with the blue and red clusters, but with specific attention for temperature monitoring, and the main technology to do this, namely radio frequency identification or RFID. Where in the second cluster discussed above the focus is on predicting and explaining the internal conditions of reefer containers, this stream of research focuses on accurate monitoring. With 14 papers discussing the application of RFID technology in reefer containers, this constitutes another important sub-stream of research (e.g. Amador et al., 2009; Ji and Han, 2012; Bollen et al., 2015; Jiménez-Ariza et al., 2015), surveyed by two review of research the use of sensor networks to monitor fruit during transport. (Costa et al., 2013; Ruiz-Garcia et al., 2007). Important questions include the type of sensors to use and their placing within the container to ensure the most accurate temperature reading (Laniel et al., 2011, 2009; Laniel and Emond, 2010). The link with the second cluster of research (marked in blue) is made by studies incorporating sensor measurement data in the modeling of temperature behavior inside a container (e.g. Amador et al., 2009; Jiménez-Ariza et al., 2015; Badia-Melis et al., 2016).

Cluster 4 (marked in red): This cluster also shows a close association with the two clusters discussed above. The most important nuance lies in the fact that research within this cluster tends to focus most on the cargo itself - particularly fruit - and its behavior during temperature-controlled transport. Most studies focus on one type of product specifically, and test how well its quality is preserved under different temperature, atmosphere, and stowage conditions:

- Bananas (Arduino et al., 2015; Jedermann et al., 2013; Jedermann and Lang, 2017; Lin et al., 2017; Snowdon, 2010)

- Grapes (De Lima, 2015)

- Pineapple (Abdullah et al., 2000; Amador et al., 2009; Chan, 2011; Nor Hanis Aifaa et al., 2011)

- Cut flowers (Shelton et al., 1996; Woltering et al., 2018)

- Mangos (De Mello Vasconcelos et al., 2019; Kienzle et al., 2012; Schouten et al., 2018; Setyawan et al., 2013; Van Der Waal and Zongo, 2011)

- Tomatoes (López et al., 2003)

- Plums (Punt and Huysamer, 2005)

- Persimmon (Fahmy and Nakano, 2013)

- Papaya (Rohani and Zaipun, 2007)

- Apples (Getahun et al., 2017b, 2017a) 


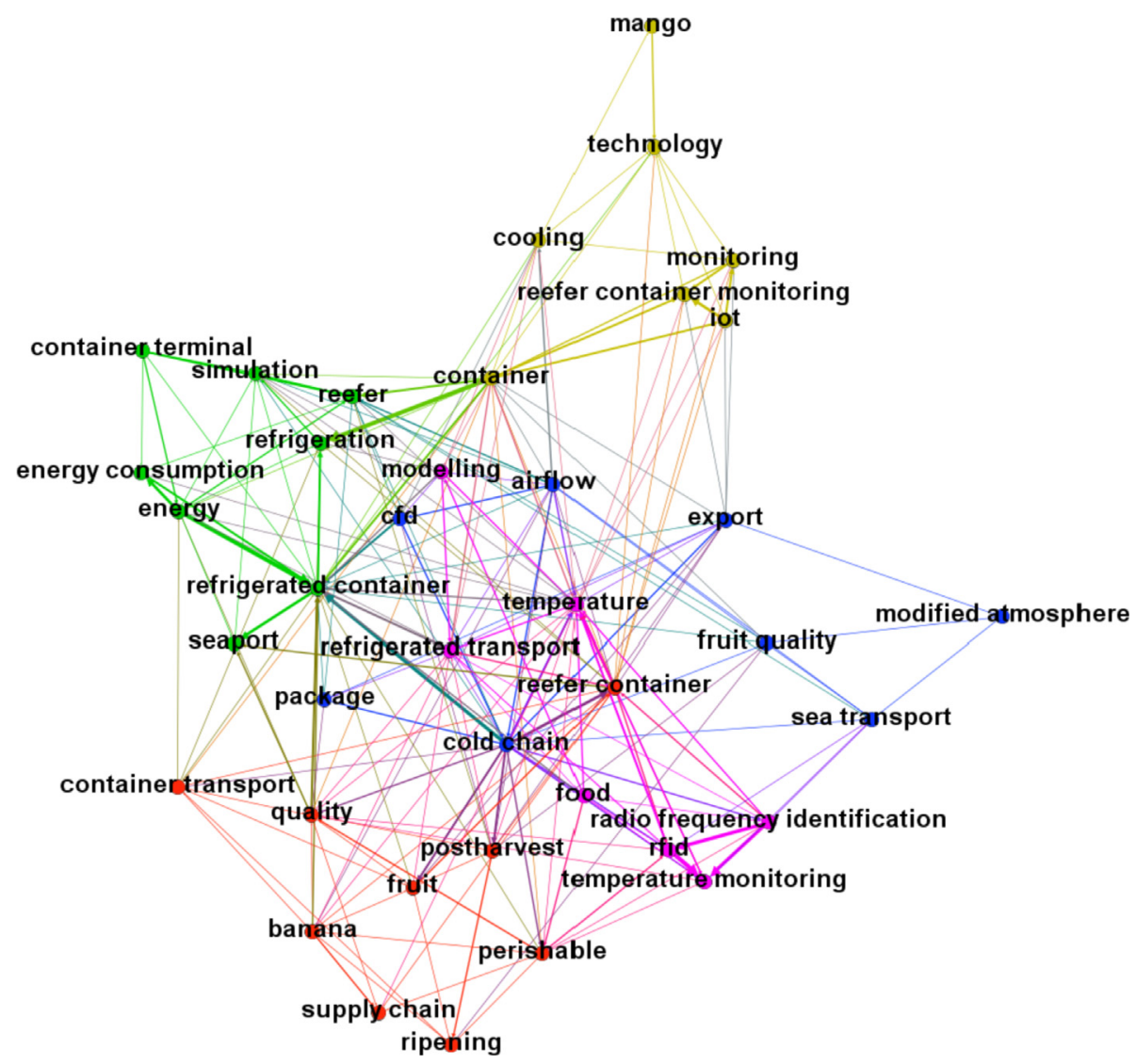

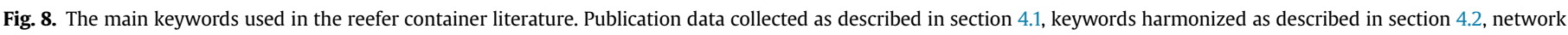
visualized using VOSviewer (Van Eck and Waltman, 2010) and Gephi (Gephi.org, 2017) software.

- Citrus (Defraeye et al., 2015b, 2015a; Gazit and Kaspi, 2017; Tauriello et al., 2015; Wu et al., 2018)

- Kiwi (Bollen et al., 2015; Harvey et al., 1983)

Other studies focus on multiple types of fruit from one export market (Goedhals-Gerber et al., 2015; Morris et al., 2003) or of the same category (Goedhals-Gerber et al., 2017; Piala and David, 2016). Some studies also show overlap with the two clusters discussed above, for example reporting on specific experiments with temperature monitoring of shipments of a certain type of cargo.

The most important type of research question in this sub-field is how the quality of a certain type of conditioned cargo can be preserved best during transit in a reefer container. None of these product-specific studies deal with frozen cargoes, which is to be expected due to the fact that fresh cargo is more sensitive, and places higher requirements on transport conditions because of the additional concerns that arise specifically for fresh foods (respiration, transpiration, and ripening).

Cluster 5 (marked in green): This last cluster shows a predominant focus on refrigeration technology, and the associated energy use of reefer containers in transit and in ports. Some studies focus on the energy use of the reefer unit itself, including experimental (Fitzgerald et al., 2011) and simulation studies (Budiyanto et al., 2019a). Several strategies have been proposed to optimize reefer unit functioning (Filina-Dawidowicz and Filin, 2019; Lukasse et al., 2011; Sorensen et al., 2015; Van Der Sman and Verdijck, 2003) or reefer container design (Copertaro et al., 2016) for energy saving.

The last few years, more attention has been given to the growing relevance of reefer containers for ports' and terminals' energy management. As the reefer market grows and container ships are constructed at increasingly large scale sizes, ports and terminals have to deal with pronounced arrival peaks of reefers. This creates logistical bottlenecks (for example at terminal gates where shippers want to pick up their time-sensitive cargoes as fast as possible) as well as energy demand peaks, that can be expensive for terminals and even result in situations where terminals' power supplies are too limited to power all reefers in the yard at the same time. Recent research has investigated the causes of energy demand peaks and indeed pinpoints arrival patterns as a major driver (Van Duin et al., 2019), as well as suggested ways to reduce these energy peaks (Van Duin et al., 2018). More generally, due to the larger numbers of reefers being connected at terminals at the same time, now up to $40 \%$ of energy consumption of European container terminals is consumed by reefers (Van Duin and Geerlings, 2011), with numbers for major exporting regions in Latin America expectedly being even higher. Recognizing the impact of reefers on power consumption, researches have suggested ways to limit the effect of solar radiation on stacked reefers' energy needs (Budiyanto et al., 2019b, 2018; Budiyanto and Shinoda, 2018), and proposed new ways of designing and implementing power systems to accommodate growing numbers of reefers (Parise et al., 2019, 2018).

\subsection{Major focus areas and miscellaneous research topics}

It should be noted that (due to the threshold of 5 occurrences for the keywords to be included) these given areas discussed above are the major focus areas, rather than all topics covered. Nevertheless, it should serve as a high-level illustration of the main focus areas in academic research on reefer containers, as well as their linkages. 
The majority of research is very focused: Most studies focus on one specific phase of the supply chain (postharvest and container loading operations; container terminal handling; liner shipping with specific attention for reefers; hinterland transport and repositioning), on one specific type of cargo or trade (e.g. banana's, blueberries, or the New Zealand kiwi export), or on one aspect of the technology of the reefer container (e.g. monitoring and control, cooling technology, temperature and airflow behavior, energy consumption, or the issue of making the reefer 'intelligent' using a combination of new technologies such as big data and the internet of things).

Some miscellaneous topics that have not been included in the bibliometric network above include:

- Reefer container servicing at terminals (Filina-Dawidowicz et al., 2015; Filina-Dawidowicz and Gajewska, 2018; Filinadawidowicz and Ph, 2014; Hartmann, 2013)

- Governance issues including cargo claims (Snowdon, 2014), data governance (Jung and Kim, 2015) and sustainability transitions (Castelein et al., 2019b)

- Comparisons of reefer containers and conventional reefer ships (Arduino et al., 2015; Cudina and Bezić, 2019; Thanopoulou, 2012; Zhang and Lam, 2018)

- Logistics issues including port processes (Goedhals-Gerber et al., 2015), fleet planning and management (Cheaitou and Cariou, 2012; Imai and Rivera, 2001; Wang et al., 2017) and repositioning (Chao and Chen, 2015; Hjortnaes et al., 2017)

Outside of these miscellaneous research topics, by far the major focus areas have been of a technical (monitoring and control, energy, refrigeration etc.) or biological nature (product behavior and quality), with relatively less attention being paid to logistics, economics, and management-related issues. Only a handful of academic studies highlight the economic managerial aspects of reefer supply chains (Arduino et al., 2015; Castelein et al., 2019b; Galvao and Robles, 2014; Lutjen et al., 2013; Manzini and Accorsi, 2013; Menesatti et al., 2014; Rodrigue and Notteboom, 2015; Wilmsmeier and Martínez-Zarzoso, 2010). As a result of this scarce attention, our knowledge of supply chain structure, coordination, governance, and stakeholder preferences and decisionmaking is still limited.

\section{Conclusions: the reefer container market and its academic research}

The reefer container market has grown considerably, and researchers and sector stakeholders alike have come to realize that this segment of the container market should be seen as a distinct market with its own unique dynamics and demands. To inform further research on this burgeoning market, this study has aimed to provide a comprehensive overview of the development and characteristics of the reefer container market, the structure and prevalent issues of reefer container chains, and the state of academic research on this market so far.

\subsection{Findings}

The most important aspect of the reefer market's development over the last decades has been its fast growth, outstripping the growth of the dry container market by far. As shown in Section 2 of this paper, this growth has occurred due to growing demand for perishables worldwide, and as a result of a shift of cargoes from other modes (conventional reefer ships or airfreight) to reefer containers. Whereas 15 years ago, the maritime reefer market was split approximately evenly between conventional reefer ships and reefer containers, now over $80 \%$ of maritime reefer trades are containerized. The conventional reefer market has stagnated in terms of volume, and despite the introduction of fully containerized ships in the FDD (fast, direct, and dedicated services) market, it will likely play only a minor role in the maritime reefer market compared to reefer containers. Not only the volume of reefer container cargoes has grown, but also the diversity of products carried in them. Improved container technology and preservation techniques, as well as the development of dedicated equipment had steadily expanded the range of applications of reefer containers. Typically, the cargoes carried inside reefer containers (predominantly food products, but also high-value niche markets such as pharmaceutical and chemical products) have their own requirements in terms of temperature control, and sometimes controlled atmosphere.

Despite the diversity in reefer cargoes and their specific requirements, a generalized overview of what a typical reefer container supply chain looks like was desirable and outlined in Section 3 of this paper. The most important characteristic is the reefer container's role in maintaining an uninterrupted 'cold chain,' of the product remaining at or closely around a specified preservation temperature along the entire supply chain. Reefer container supply chains are very similar in structure to conventional intermodal container supply chains, as both involve the consolidation of the cargo inside a standardized intermodal container for the largest part of a transport chain. This unitization facilitates efficient handling, ensures intermodal compatibility, and helps keep costs low. However, with reefer containers, additional sensitivity and complexity are introduced by the technology of the container and the sensitive nature of the cargo. While operating, reefer containers require a constant energy supply and continuous monitoring to ensure that their contents are preserved well. In addition, the containers, and in particular the reefer units, require regular inspections, cleaning, and maintenance to ensure proper functioning. However, risks to cargo can still occur due to a multitude of technical and human errors. To limit product waste and improve reefer chain efficiency, identifying and resolving these issues is paramount.

To evaluate the extent to which the academic research is addressing the most pressing issues encountered in practice, Section 4 of this paper has provided a systematic review of the academic literature on reefer container transportation. This body of literature on reefer containers so far mostly reflects the technological advances that facilitated the growing containerization of perishable goods, namely research on refrigeration technology, temperature management, monitoring and control, postharvest handling, and product preservation. Not only has this facilitated the growth of the reefer container market, but also made it possible that the rate of product loss during long-range transportation is relatively low compared to other stages in food supply chains (such as agriculture, post-harvest handling, processing, consumption). Data from sector sources indicate that cargo loss in transit not only occurs due to equipment failure, but just as often because of breaks in container power supply (and ultimately breaks in the cold chain) due to human errors. The review shows that particularly the latter is an issue that has not received much attention in the literature so far - compared to the major research areas discussed above. This is not only related to the quality and availability of power supplies, but also a case of coordination between parties in reefer container chains. As discussed in Section 3, risks of cold chain breaks are most prevalent when custodianship of a container transfers from one party to another and the container has to be disconnected, transferred, re-connected, and transported further within a narrow timeframe. Whereas on containerships containers are plugged in for the duration of the voyage without being disconnected or 
transferred, risks from container transfer and power supply breaks are prevalent in port areas and in hinterland intermodal transport systems. An agenda for future research on reefer container transportation should accordingly include these aspects, in addition to the major areas of research already explored in the literature. The most important focus areas of such an agenda are discussed below, as well as some future prospects for the reefer market.

\subsection{Discussion}

The reefer container market itself is still in a phase of strong growth, due to growing demand for perishables worldwide, and shifts of existing trade from other modes, such as conventional reefer ships and airfreight to container shipping. Not only in terms of volume is the market growing, but also a tendency of increasing service differentiation can be distinguished - catering to newly containerized goods, sometimes using dedicated equipment and processes. The development of such niches reflects a maturing market, and the substitution effect from shifts from other modes will likely diminish when the containerization rate of the overall perishables transport market increases. However, sustained growth of consumer demand for perishables and the development of new niches within the reefer container market are both likely to drive future growth.

The existing academic literature on reefer containers reflects a predominantly technological and product-oriented focus. However, this paper shows that coordination failures and human errors are important causes of hold-up and cold chain breaks, despite being researched relatively little. Future research should take up the challenge to address these organizational issues in reefer container transportation. This includes overall supply chain coordination and prevention of hold-up at container transfer points, but specifically the role of seaports as transportation and logistics clusters where handling operations, container transfers, and hence hold-up risks converge. The position of reefer chains in seaports is still in flux, even though challenges are to be anticipated. Clients favor speed and reliability - criteria met by fast, direct, and dedicated shipping services, and small-scale dedicated terminals - yet increasingly reefer containers end up being handled in congested port areas around container terminals. A major question for carriers, terminals, and other port-related service providers is how to meet customer requirements and deal with the time-sensitivity of reefer cargoes, while still benefiting from the advantages of large-scale container transport. This not only asks for the development of new business models in the logistics sector, but also news ways for port authorities to plan prudently for these changes.

The growing embeddedness of reefer containers in the conventional container system also produces challenges for energy management of ports and terminals. Some academic research has already addressed the challenge of energy demand peaks from reefer racks and the growing number of reefers being connected at the same time (see Section 4.2, Cluster 5). As ports face increasingly complex challenges in their energy management, these questions can be extended to the use of renewable energy sources for reefer cargo cooling, and for example the application of smart grids and cold buffers. Similarly, the containerization of reefer cargoes has implications for the coordination between reefer-handling parties in intermodal chains. Earlier research on coordination in container chains has shown the manifold hold-up risks associated with container transfers in intermodal chains. For the reefer container market, the implications of coordination failures are compounded by their impact on cargo loss risk. In this area - as well as others the lessons from research on container transport in general can be evaluated and adapted to address the specific challenges of the reefer container market. An example would be the stimulation of a modal shift from hinterland trucking to more sustainable modes such as train or barge, that contribute less to traffic congestion as well. For dry containers, this has been hard to effectuate, and due to the sensitivity and perceived time-sensitivity of reefer cargoes, this may be even harder in the reefer market. Therefore, future research should address the development of appropriate intermodal services for reefer containers, including technical solutions for reliable power supply, and temperature and quality monitoring along the chain.

These potential research directions illustrate that supply chain actors and ports not only have to deal with the challenges arising from a modal shift and growth of the reefer market, but also sustainability challenges that extend beyond limiting product loss. Reducing overall energy use, increasing the share of renewables, smarter logistics concepts and modal shift - as well as the governance arrangements along supply chains and in ports that enable these developments - all must be addressed in an evolution to a more sustainable conditioned transport market.

\section{Author contribution statement}

Castelein: Conceptualization, Data curation, Formal Analysis, Investigation, Methodology, Software, Validation, Visualization, Writing - original draft, Writing - review \& editing.

Geerlings: Conceptualization, Funding acquisition, Project administration, Resources, Supervision, Validation, Writing - review \& editing.

Van Duin: Conceptualization, Funding acquisition, Project administration, Resources, Supervision, Validation, Writing - review \& editing.

\section{Funding acknowledgement}

The authors are working in research project EURECA (Effective Use of Reefer Containers Through the Port of Rotterdam - A Transition Oriented Approach), with project number 438-15-505 of the Netherlands Organization for Scientific Research (NWO), cofinanced by SmartPort, ABB, and Seamark. None of the funding organizations were involved in the study design, interpretation or analysis of data, or the writing of this manuscript.

\section{Netherlands Organisation for Scientific Research}

\section{Declaration of competing interest}

The authors declare that they have no known competing financial interests or personal relationships that could have appeared to influence the work reported in this paper.

\section{Funding Acknowledgement}

The authors are working in research project EURECA (Effective Use of Reefer Containers Through the Port of Rotterdam - A Transition Oriented Approach), with project number 438-15-505 of the Netherlands Organization for Scientific Research (NWO), cofinanced by SmartPort, ABB, and Seamark. None of the funding organizations were involved in the study design, interpretation or analysis of data, or the writing of this manuscript. 


\section{References}

North of England P\&I Association, 2013. Loss Prevention Briefing (Newcastle upon Tyne).

Abdullah, H., Rohaya, M.A., Rosli, H., Selamat, M.M., 2000. Handling and transportation trial of pineapple by sea shipment from Malaysia to the United Kingdom. Acta Hortic. 317-327. https://doi.org/10.17660/ ActaHortic.2000.529.38.

Accorsi, R., Manzini, R., Ferrari, E., 2014. A comparison of shipping containers from technical, economic and environmental perspectives. Transport. Res. Transport Environ. 26, 52-59. https://doi.org/10.1016/j.trd.2013.10.009.

Amador, C., Emond, J.P., Nunes, M.C.D.N., 2009. Application of RFID technologies in the temperature mapping of the pineapple supply chain. Sens. Instrum. Food Qual. Saf. 3, 26-33. https://doi.org/10.1007/s11694-009-9072-6.

American Journal of Transport, 2010. Maersk Line partners with Aqualife to transport shellfish by container from Canada to EU [WWW Document]. Am. J. Transplant. URL https://www.ajot.com/news/maersk-line-partners-withaqualife-to-transport-shellfish-by-container-from accessed 1.20.20.

American Journal of Transport, 2018. CMA CGM introduces REEFLEX: a new and unique system for the transportation of liquids by container [WWW Document]. Am. J. Transplant. URL https://www.ajot.com/news/cma-cgmintroduces-reeflex-a-new-and-unique-system-for-the-transportation-ofliquids-by-container accessed 1.20.20.

Arduino, G., Carrillo Murillo, D., Parola, F., 2015. Refrigerated container versus bulk: evidence from the banana cold chain. Marit. Pol. Manag. 42, 228-245. https:/ doi.org/10.1080/03088839.2013.851421.

Badia-Melis, R., Mc Carthy, U., Uysal, I., 2016. Data estimation methods for predicting temperatures of fruit in refrigerated containers. Biosyst. Eng. 151, 261-272. https://doi.org/10.1016/j.biosystemseng.2016.09.009.

Barnard, B., 2016. CMA CGM takes aim at air cargo market with new lobster container. J. Commer.

Behdani, B., Fan, Y., Bloemhof, J., 2018. Cool Chain and Temperature-Controlled Transport: an Overview of Concepts, Challenges and Technologies.

Behdani, B., Fan, Y., Bloemhof, J.M., 2019. Cool chain and temperature-controlled transport: an overview of concepts, challenges, and technologies. In: Accorsi, R., Manzini, R. (Eds.), Sustainable Food Supply Chains. Academic Press, pp. 167-183. https://doi.org/10.1016/B978-0-12-813411-5.00012-0.

Bollen, A.F., Tanner, D.J., Soon, C.B., East, A.R., Dagar, A., Sharshevsky, H., Mowat, A.D., Heyes, J.A., Pelech, Y., 2015. Wireless temperature monitoring system in a global kiwifruit supply Chain. Acta Hortic. 1091, 205-212.

Budiyanto, M.A., Shinoda, T., 2018. The effect of solar radiation on the energy consumption of refrigerated container. Case Stud. Therm. Eng. 12, 687-695. https://doi.org/10.1016/j.csite.2018.09.005.

Budiyanto, M.A., Shinoda, T., Sunaryo, Nugroho, F.A., Wibowo, B., 2018. Estimated of energy saving from the application of roof shade on the refrigerated containe storage yard. J. Adv. Res. Fluid Mech. Therm. Sci. 46, 114-121.

Budiyanto, M.A., Nasruddin, Zhafari, F., 2019a. Simulation study using buildingdesign energy analysis to estimate energy consumption of refrigerated container. Energy Procedia 207-211. https://doi.org/10.1016/ egypro.2018.11.129.

Budiyanto, M.A., Sunaryo, Fernanda, H., Shinoda, T., 2019b. Effect of azimuth angle on the energy consumption of refrigerated container. Energy Procedia 201-206. https://doi.org/10.1016/egypro.2018.11.128.

Castelein, B., Geerlings, H., Van Duin, R., 2019a. Cold chain strategies for seaports. Towards a worldwide policy classification and analysis. In: Witlox, F. (Ed.) Moving towards More Sustainable Mobility and Transport through Smart Systems. Proceedings of the BIVEC-GIBET Transport Research Days 2019. Ghent.

Castelein, B., Van Duin, R., Geerlings, H., 2019b. Identifying dominant stakeholder perspectives on sustainability issues in reefer transportation. A Q-method study in the port of Rotterdam. Sustainability 11, 3425.

Chan, Y.K., 2011. Pineapple breeding: fulfilling expectations of the global supply chain. Acta Hortic. 902, 109-114.

Chao, S., Chen, C., 2015. Applying a time-space network to reposition reefer containers among major Asian ports. Res. Transp. Bus. Manag. 17, 65-72. https:/ doi.org/10.1016/j.rtbm.2015.10.006.

Cheaitou, A., Cariou, P., 2012. Liner shipping service optimisation with reefer containers capacity: an application to northern Europe-South America trade Marit. Pol. Manag. 39, 589-602. https://doi.org/10.1080/ 03088839.2012.728726.

Copertaro, B., Principi, P., Fioretti, R., 2016. Thermal performance analysis of PCM in refrigerated container envelopes in the Italian context - numerical modeling and validation. Appl. Therm. Eng. 102, 873-881. https://doi.org/10.1016/ j.applthermaleng.2016.04.050.

Costa, C., Antonucci, F., Pallottino, F., Aguzzi, J., Sarria, D., Menesatti, P., 2013. A review on agri-food supply chain traceability by means of RFID technology. Food Bioprocess Technol. 6, 353-366. https://doi.org/10.1007/s11947-0120958-7.

Čudina, P., Bezić, A., 2019. Reefer vessel versus container ship. Brodogradnja 70 , 129-141. https://doi.org/10.21278/brod70109.

Darmon, N., Drewnowski, A., 2008. Does social class predict diet quality? Am. J. Clin. Nutr. 87, 1107-1117.

De Lima, C.P.F., 2015. Maintaining table grape quality by applying quarantine treatments during cooling. Acta Hortic. 55-61.

De Mello Vasconcelos, O.C., De Campos Ferreira, G.J.B., De Castro Silva, J., Teruel
Mederos, B.J., De Freitas, S.T., 2019. Development of an artificial fruit prototype for monitoring mango skin and flesh temperatures during storage and transportation. Postharvest Biol. Technol. 158 https://doi.org/10.1016/ j.postharvbio.2019.110956.

Defraeye, T., Cronje, P., Verboven, P., Opara, U.L., Nicolai, B., 2015a. Exploring ambient loading of citrus fruit into reefer containers for cooling during marine transport using computational fluid dynamics. Postharvest Biol. Technol. 108, 91-101. https://doi.org/10.1016/j.postharvbio.2015.06.004.

Defraeye, T., Verboven, P., Opara, U.L., Nicolai, B., Cronjé, P., 2015b. Feasibility of ambient loading of citrus fruit into refrigerated containers for cooling during marine transport. Biosyst. Eng. 134, 20-30. https://doi.org/10.1016/ j.biosystemseng.2015.03.012.

Defraeye, T., Nicolai, B., Kirkman, W., Moore, S., Van Niekerk, S., Verboven, P. Cronjé, P., 2016. Integral performance evaluation of the fresh-produce cold chain: a case study for ambient loading of citrus in refrigerated containers. Postharvest Biol. Technol. 112, 1-13. https://doi.org/10.1016/ j.postharvbio.2015.09.033.

Dittmer, P., Veigt, M., Heidmann, N., Paul, S., 2012. The intelligent container as a part of the internet of things. A framework for quality-driven distribution for perishables. In: 2012 IEEE International Conference on Cyber Technology in Automation, Control, and Intelligent Systems (CYBER). https://doi.org/10.1109/ CYBER.2012.6392555.

Doe, L., 2017. Hapag-Lloyd makes huge Maersk reefer container order [WWW Document]. Port Technol. URL https://www.porttechnology.org/news/hapag_ lloyd_orders_3700_maersk_reefer_containers/ accessed 1.20.20.

Doe, L., 2018. New HMM ultra-freezer reefer service takes on air freight [WWW document]. Port Technol. URL https://www.porttechnology.org/news/new_ hmm_ultra_freezer_reefer_service_takes_on_air_freight/ accessed 1.20.20.

Drewry, 2016. Reefer Shipping Market Review and Forecast (London).

Drewry Maritime Research, 2016. Reefer Shipping Market Review and Forecast. Annual Report 2016/17.

Dynamar, 2017. Reefer analysis. Market structure. In: Conventional. Containers. Alkmaar.

Fahmy, K., Nakano, K., 2013. Favorable transportation conditions preventing quality loss of 'Jiro' Persimmon for exports. Acta Hortic. 73-80.

FAO, 2011. Global Food Losses and Food Waste - Extent, Causes and Prevention (Rome).

Filina-Dawidowicz, L., Filin, S., 2019. Innovative energy-saving technology in refrigerated containers transportation. Energy Effic. 12, 1151-1165. https:// doi.org/10.1007/s12053-018-9729-2.

Filina-Dawidowicz, L. Gajewska, T. 2018. Customer satisfaction in the field of comprehensive service of refrigerated containers in seaports. Period. Polytech. Transp. Eng. 46, 151-157. https://doi.org/10.3311/PPtr.10824.

Filina-dawidowicz, L., Ph, D., 2014. Rationalization of servicing reefer containers in sea port area with taking into account risk influence. Pol. Marit. Res. 21, 76-85. https://doi.org/10.2478/pomr-2014-0022.

Filina-Dawidowicz, L., Iwańkowicz, R., Rosochacki, W., 2015. Risk measures of load loss during service of refrigerated containers in seaports. Arch. Transp. 34, 19-27. https://doi.org/10.5604/08669546.1169208.

Fitzgerald, W.B., Howitt, O.J.A., Smith, I.J., Hume, A., 2011. Energy use of integral refrigerated containers in maritime transportation. Energy Pol. 39, 1885-1896. https://doi.org/10.1016/j.enpol.2010.12.015.

Galvao, C.B., Robles, L., 2014. The south America east coast reefer Cargo : a diagnosis of a competitive market. In: IBIMA, Rome, Italy, 13-14 Nov. 2013, pp. 1891-1904. https://doi.org/10.5171/2014.309732.

Gazit, Y., Kaspi, R., 2017. An additional phytosanitary cold treatment against ceratitis capitata (Diptera: tephritidae) in 'Oroblanco' citrus fruit. J. Econ. Entomol. 110, 790-792. https://doi.org/10.1093/jee/tow291.

Gehrke, J.D., Behrens, C., Jedermann, R., Morales Kluge, E., 2006. The Intelligent Container-Toward Autonomous Logistic Processes. Demo Presentations, Universität Bremen.

Gephiorg, 2017. Gephi 0.9.2.

Getahun, S., Ambaw, A., Delele, M., Meyer, C.J., Opara, U.L., 2017a. Analysis of airflow and heat transfer inside fruit packed refrigerated shipping container: Part I model development and validation. J. Food Eng. 203, 58-68. https://doi.org/ 10.1016/j.jfoodeng.2017.02.010.

Getahun, S., Ambaw, A., Delele, M., Meyer, C.J., Opara, U.L., 2017b. Analysis of airflow and heat transfer inside fruit packed refrigerated shipping container: Part II evaluation of apple packaging design and vertical flow resistance. J. Food Eng. 203, 83-94. https://doi.org/10.1016/j.jfoodeng.2017.02.010.

Goedhals-Gerber, L.L., Haasbroek, L., Freiboth, H., van Dyk, F.E., 2015. An analysis of the influence of logistics activities on the export cold chain of temperature sensitive fruit through the Port of Cape Town. J. Transp. Supply Chain Manag. 9 https://doi.org/10.4102/jtscm.v9i1.201.

Goedhals-Gerber, L.L., Stander, C., Van Dyk, F.E., 2017. Maintaining cold chain integrity: temperature breaks within fruit reefer containers in the Cape Town Container Terminal. South. Afric. Bus. Rev. 21, 362-384.

Guerrero, D., Rodrigue, J., 2014. The waves of containerization: shifts in global maritime transportation. J. Transport Geogr. 34, 151-164. https://doi.org/ 10.1016/j.jtrangeo.2013.12.003.

Haass, R., Dittmer, P., Veigt, M., Lutjen, M., 2015. Reducing food losses and carbon emission by using autonomous control - a simulation study of the intelligent container. Int. J. Prod. Econ. 164, 400-408. https://doi.org/10.1016/ j.ijpe.2014.12.013.

Hamburg Süd, 2010. Stay Cool, We Care (Hamburg). 
Hartmann, S., 2013. Scheduling reefer mechanics at container terminals. Transp. Res. Part E Logist. Transp. Rev. 51, 17-27. https://doi.org/10.1016/ j.tre.2012.12.007.

Harvey, J.M., Harris, C.M., Marousky, F.J., 1983. Transit temperatures and quality maintenance in export shipments of kiwifruit (Actinidia chinensis Planch.). Int J. Refrig. 6, 219-224. https://doi.org/10.1016/0140-7007(83)90078-6.

Healey, B., 2018. Everything you should know about reefer shipping. Port Technol. Hjortnaes, T., Wiegmans, B., Negenborn, R.R., Zuidwijk, R.A., Klijnhout, R., 2017. Minimizing cost of empty container repositioning in port hinterlands, while taking repair operations into account. J. Transport Geogr. 58, 209-219. https:// doi.org/10.1016/j.jtrangeo.2016.12.015.

Imai, A., Rivera, F., 2001. Strategic fleet size planning for maritime refrigerated containers. Marit. Pol. Manag. 28, 361-374. https://doi.org/10.1080/ 03088830010020629.

Issa, S., Lang, W., 2016. Airflow simulation inside reefer containers. In: Kotzab, H., Pannek, J., Thoben, K. (Eds.), Dynamics in Logistics, Lecture Notes in Logistics. Springer, Cham, pp. 303-311. https://doi.org/10.1007/978-3-319-23512-7_29.

James, S.J., James, C., Evans, J.A., 2006. Modelling of food transportation systems - a review. Int. J. Refrig. 29, 947-957. https://doi.org/10.1016/j.ijrefrig.2006.03.017.

Jedermann, R., Lang, W., 2017. Computational fluid dynamics modelling of deviating airflow and cooling conditions in banana containers. Acta Hortic. 193-200. https://doi.org/10.17660/ActaHortic.2017.1154.25.

Jedermann, R., Moehrke, A., Lang, W., 2010. Supervision of banana transports by the intelligent container. In: Kreyenschmidt, J. (Ed.), Coolchain-Management, 4th International Workshop. University Bonn, Bonn, pp. 75-84.

Jedermann, R., Geyer, M., Praeger, U., Lang, W., 2013. Sea transport of bananas in containers - parameter identification for a temperature model. J. Food Eng. 115, 330-338. https://doi.org/10.1016/j.jfoodeng.2012.10.039.

Jedermann, R., Nicometo, M., Uysal, I., Lang, W., 2014a. Reducing food losses by intelligent food logistics. Philos. Trans. R. Soc. Ser. A, Math. Phys. Eng. Sci. 372, 1-20. https://doi.org/10.1098/rsta.2013.0302.

Jedermann, R., Praeger, U., Geyer, M., Lang, W., 2014b. Remote quality monitoring in the banana chain. Philos. Trans. R. Soc. A - Math. Phys. Eng. Sci. 372 https:// doi.org/10.1098/rsta.2013.0303.

Ji, J., Han, H., 2012. Inside temperature monitoring system of marine reefer containers based on RFID. Appl. Mech. Mater. 120, 485-488. https://doi.org/10. 4028/www.scientific.net/AMM.120.485.

Jiménez-Ariza, H.T., Correa, E.C., Diezma, B., Moya-González, A., Arranz, F.J., Barreiro, P., 2015. Multi-distributed wireless sensors for monitoring a long distance transport in a reefer container. Int. J. Postharvest Technol. Innovation 5, 149-166. https://doi.org/10.1504/IJPTI.2015.074327.

Johnson, E., 2019. Funding to fuel Traxens' container line orders. J. Commer.

Journal of Commerce Staff, 2014. Maersk to launch new reefer technology. J. Commer.

Jung, J.U., Kim, H.S., 2015. Big data governance for smart logistics: a value-added perspective. In: Balandin, S., Andreev, S., Koucheryavy, Y. (Eds.), Lecture Notes in Computer Science. Springer Verlag, Cham, pp. 95-103. https://doi.org/ 10.1007/978-3-319-23126-6_9.

Kienzle, S., Sruamsiri, P., Carle, R., Sirisakulwat, S., Spreer, W., Neidhart, S., 2012. Harvest maturity detection for "Nam Dokmai \#4" mango fruit (Mangifera indica L.) in consideration of long supply chains. Postharvest Biol. Technol. 72, 64-75. https://doi.org/10.1016/j.postharvbio.2012.04.011.

Laniel, M., Emond, J.-P., 2010. Mapping of RFID tag readability in relation to the food content in a refrigerated sea container at $915 \mathrm{MHz}$. Innovat. Food Sci. Emerg. Technol. 11, 703-706. https://doi.org/10.1016/j.ifset.2010.06.005.

Laniel, M., Emond, J.-P., Altunbas, A.E., 2009. RFID behavior study in enclosed marine container for real time temperature tracking. Sens. Instrum. Food Qual. Saf. 3, 34-40. https://doi.org/10.1007/s11694-009-9075-3.

Laniel, M., Emond, J.-P., Altunbas, A.E., 2011. Effects of antenna position on readability of RFID tags in a refrigerated sea container of frozen bread at 433 and 915 MHz. Transport. Res. C Emerg. Technol. 19, 1071-1077. https://doi.org/10.1016/ j.trc.2011.06.008.

Likar, K., Jevšnik, M., 2006. Cold chain maintaining in food trade. Food Contr. 17, 108-113. https://doi.org/10.1016/j.foodcont.2004.09.009.

Lin, X., Negenborn, R.R., Lodewijks, G., 2016. Towards quality-aware control of perishable goods in synchromodal transport networks. IFAC-PapersOnLine 49, 132-137. https://doi.org/10.1016/j.ifacol.2016.10.025.

Lin, X., Negenborn, R.R., Duinkerken, M.B., Lodewijks, G., 2017. Quality-aware modeling and optimal scheduling for perishable good distribution networks: the case of banana logistics. Lect. Notes Comput. Sci. Comput. Logist. https:// doi.org/10.1007/978-3-319-68496-3_32.

López, M.D., Contreras, M., Fernández-Alba, A.R., 2003. Time evolution of tomato quality parameters versus storage conditions. Acta Hortic. 619-624. https:// doi.org/10.17660/ActaHortic.2003.604.75.

Luchsinger, L., Escalona, V., Montenegro, J.P., Lizana, L.A., 2018. Survey of the types of stowage used in refrigerated containers for the transport of export fresh fruit. Acta Hortic. https://doi.org/10.17660/ActaHortic.2018.1194.153.

Lukasse, L.J.S., Baerentz, M.B., Kramer-Cuppen, J.E.D., 2011. Quest II : reduction of CO2 emissions of reefer containers. In: 23rd IIR International Congress of Refrigeration, pp. 3203-3210.

Lutjen, M., Dittmer, P., Veigt, M., 2013. Quality driven distribution of intelligent containers in cold chain logistics networks. Prod. Eng. Res. Dev. 7, 291-297. https://doi.org/10.1007/s11740-012-0433-3.

Manzini, R., Accorsi, R., 2013. The new conceptual framework for food supply chain assessment. J. Food Eng. 115, 251-263. https://doi.org/10.1016/ j.jfoodeng.2012.10.026.

Matthias, D.M., Robertson, J., Garrison, M.M., Newland, S., Nelson, C., 2007. Freezing temperatures in the vaccine cold chain: a systematic literature review. Vaccine 25, 3980-3986. https://doi.org/10.1016/j.vaccine.2007.02.052.

Mees, H.O., Lin, X., Negenborn, R.R., 2018. Towards a flexible banana supply chain: dynamic reefer temperature management for reduced energy consumption and assured product quality. In: Dynamics in Logistics, pp. 223-230. https://doi.org/ 10.1007/978-3-319-74225-0_31.

Menesatti, P., Pallottino, F., Prisco, N. De, Laderchi, D.R., 2014. Intermodal vs. conventional logistic of refrigerated products: a case study from Southern to Northern Europe. Agric. Eng. Int. CIGR J. 16, 80-87.

Moher, D., Liberati, A., Tetzlaff, J., Altman, D.G., Group, T.P., 2009. Preferred reporting Items for systematic reviews and meta-analyses: the PRISMA statement. PLoS Med. 6, e1000097.

Montanari, R., 2008. Cold chain tracking: a managerial perspective. Trends Food Sci. Technol. 19, 425-431. https://doi.org/10.1016/j.tifs.2008.03.009.

Morris, S.C., Jobling, J.J., Tanner, D.J., Forbes-Smith, M.R., 2003. Prediction of storage or shelf life for cool stored fresh produce transported by reefers. Acta Hortic. 604, 305-311.

Nightingale, L., 2015. Out with the old, in with the teu? [WWW Document]. Lloyd's List. URL https://lloydslist.maritimeintelligence.informa.com/LL016613/Outwith-the-old-in-with-the-teu accessed 1.20.20.

Nor Hanis Aifaa, Y., Zaulia, O., Nur Aida, M.P., Habsah, M., Azhar, M.N., Zaipun, M.Z. 2011. Effect of storage duration on the quality of fresh-cut "Josapine" pineapple. Acta Hortic. 479-486. https://doi.org/10.17660/ActaHortic.2011.902.61.

Osler, D., 2019. Great White Fleet to replace reefers with cellular boxships [WWW Document]. Lloyd's List. URL https://loydslist.maritimeintelligence.informa. com/LL1125741/Great-White-Fleet-to-replace-reefers-with-cellular-boxships accessed 1.20.20.

Parise, G., Parise, L., Di Ruggiero, M., Falanga, G., Su, C.-L., Ben Chavdanan, P., 2018 Systems design criteria for uniformly distributed loads. The refrigerated containers park. IEEE Trans. Ind. Appl. 55, 2320-2326. https://doi.org/10.1109/ IAS.2018.8544487.

Parise, G., Parise, L., Di Ruggiero, M., Falanga, G., Su, C.-L., Liao, C.-H., Ben Chavdarian, P., 2019. Systems design criteria for refrigerated container parks. IEEE Trans. Ind. Appl. 55, 2320-2326. https://doi.org/10.1109/TIA.2019.2891612.

Piala, P., David, A., 2016. Transport of tropical fruits to central europe. Nase More 63 , 62-65. https://doi.org/10.17818/NM/2016/2.4.

Punt, H., Huysamer, M., 2005. Temperature variances in a $12 \mathrm{~m}$ integral reefer container carrying plums under a dual temperature shipping regime. Acta Hortic. 687, 289-296.

Refrigerated Transporter, 2015. Klinge Corp begins production of tank container reefer unit [WWW Document]. Refrig. Transp. URL https://www refrigeratedtransporter.com/featured-products/article/21719770/klinge-corpbegins-production-of-tank-container-reefer-unit accessed 1.20.20.

Rodrigue, J.-P., Notteboom, T., 2015. Looking inside the box: evidence from the containerization of commodities and the cold chain. Marit. Pol. Manag. 42, 207-227. https://doi.org/10.1080/03088839.2014.932925.

Rodríguez-Bermejo, J., Barreiro, P., Robla, J.I., Ruiz-García, L., 2007. Thermal study of a transport container. J. Food Eng. 80, 517-527. https://doi.org/10.1016/ j.jfoodeng.2006.06.010.

Rohani, M.Y., Zaipun, M.Z., 2007. MA storage and transportation of 'Eksotika' papaya. Acta Hortic. https://doi.org/10.17660/ActaHortic.2007.740.37.

Ruiz-Garcia, L., Barreiro, P., Rodriguez-Bermejo, J., Robla, J.I., 2007. Review. Monitoring the intermodal, refrigerated transport of fruit using sensor networks Spanish J. Agric. Res. 5, 142-156. https://doi.org/10.5424/234.

Schouten, R.E., Fan, S., Verdonk, J.C., Wang, Y., Kasim, N.F.M., Woltering, E.J., Tijskens, L.M.M., 2018. Mango firmness modeling as affected by transport and ethylene treatments. Front. Plant Sci. 9, 1647. https://doi.org/10.3389/ fpls.2018.01647.

Seatrade, 2019. Simply Seatrade.

Setyawan, N., Mulyawanti, I., Setyabudi, D.A., Rachmat, R., 2013. Trials for application of handling technology in mango export. Acta Hortic. 405-411.

Shelton, M.D., Walter, V.R., Brandl, D., Mendez, V., 1996. The effects of refrigerated, controlled-atmosphere storage during marine shipment on insect mortality and cut-flower vase life. HortTechnology 6, 247-250.

Smale, N.J., Moureh, J., Cortella, G., 2006. A review of numerical models of airflow in refrigerated food applications. Int. J. Refrig. 29, 911-930. https://doi.org/ 10.1016/j.ijrefrig.2006.03.019.

Snowdon, A.L., 2010. Carriage of bananas (musa spp.) in refrigerated ships and containers: preshipment and shipboard factors influencing cargo out-turn condition. Acta Hortic. 375-383.

Snowdon, A.L., 2014. Fruits and vegetables in international trade. Forensic aspects of cargo claims. In: Postharvest Handling. Elsevier Inc., pp. 505-518. https:// doi.org/10.1016/B978-0-12-408137-6.00018-1

Sorensen, K.K., Skovrup, M.J., Jessen, L.M., Stoustrup, J., 2015. Modular modeling of a refrigeration container. Int. J. Refrig. 55, 17-29. https://doi.org/10.1016/ j.ijrefrig.2015.03.017.

Sowinski, L.L., 2015a. New reefer technology preserves perishables for extended distances. J. Commer.

Sowinski, L.L., 2015b. Investments being made to build integrated cold chain. J. Commer.

Tan, W.Z., 2017. Container shipping lines set to grow reefer market share [WWW Document]. Lloyd's List. URL https://lloydslist.maritimeintelligence.informa. com/LL111630/Container-shipping-lines-set-to-grow-reefer-market-share 
accessed 1.20 .20

Tauriello, A., Renzo, G.C.D., Altieri, G., Strano, M.C., Genovese, F., Calandra, M. 2015. Simulation of cold treatment during a cargo shipment of citrus fruit. Acta Hortic. 1065, 1685-1692. https://doi.org/10.17660/ActaHortic.2015.1065.216.

Thanopoulou, H., 2012. Bulk reefer market economics in a product life cycle perspective. Marit. Pol. Manag. 39, 281-296. https://doi.org/10.1080/ 03088839.2011 .625992$.

UK P\&I Club, 2017. Top 25 Causes of Container Claims. A Loss Prevention Advice Checklist for Container Operators.

UNCTAD, 2012. Review of Maritime Transport 2012 (New York and Geneva).

Van Der Sman, R.G.M., Verdijck, G.J.C., 2003. Model predictions and control of conditions in a CA-reefer container. Acta Hortic. 600, 163-171.

Van Der Waal, J.W.H., Zongo, A., 2011. Developing a fresh mango export value chain with West-African smallholder mango farmers. Acta Hortic. 895, 283-291.

Van Duin, J.H.R., Geerlings, H., 2011. Estimating CO2 footprints of container terminal port-operations. Int. J. Sustain. Dev. Plann. 6, 459-473. https://doi.org/10.2495 SDP-V6-N4-459-473.

Van Duin, J.H.R., Geerlings, H., Verbraeck, A., Nafde, T., 2018. Cooling down: a simulation approach to reduce energy peaks of reefers at terminals. J. Clean. Prod. 193, 72-86. https://doi.org/10.1016/j.jclepro.2018.04.258.

Van Duin, J.H.R., Geerlings, H., Tavasszy, L.A., Bank, D.L., 2019. Factors causing peak energy consumption of reefers at container terminals. J. Shipp. Trade 4, 1 . https://doi.org/10.1186/s41072-019-0040-y.

Van Eck, N.J., Waltman, L., 2010. VOSviewer, a computer program for bibliometric mapping. Scientometrics 84, 523-538.

Van Marle, G., 2011. Reefer box costs hold back lines. Lloyd's List.

Van Oosterhout, M., 2008. Organizations and flows in the network. Technol. Info. Oper. Manag. 2, 176-185.

Veritas Health Innovation, 2019. Covidence systematic review software. Available at. www.covidence.org.

Wagenaar, R.W., 1992. Business network redesign: lessons from the Port of Rotterdam simulation game. In: Gricar, J. (Ed.), Proceedings of the 5th International Conference on EDI. Bled, Slovenia, pp. 390-404.

Wang, K., Liu, W., Wang, S., Liu, Z., 2017. Optimal reefer slot conversion for container freight transportation. Marit. Pol. Manag. 44, 1-17. https://doi.org/10.1080/ 03088839.2017.1335899.

Wilmsmeier, G., 2014. Energy consumption and efficiency: emerging challenges from reefer trade in South American container terminals. FAL Bull. 329, 1-9.

Wilmsmeier, G., Martínez-Zarzoso, I., 2010. Determinants of maritime transport costs - a panel data analysis for Latin American trade. Transport. Plann. Technol. 33, 37-41. https://doi.org/10.1080/03081060903429447.

Wold Cargo News Editorial, 2018. New reefers for chiquita [WWW document]. World Cargo News. URL. https://www.worldcargonews.com/news/news/newreefers-for-chiquita-50405. accessed 1.20.20.

Woltering, E., Paillart, M., Drosou, E., Brouwer, B., 2018. Effect of long-term storage on physiology of cut roses. Acta Hortic. 379-387. https://doi.org/10.17660/ ActaHortic.2018.1201.51.

Wu, W., Cronje, P., Nicolai, B., Verboven, P., Opara, U.L., Defraeye, T., 2018. Virtual cold chain method to model the postharvest temperature history and quality evolution of fresh fruit - a case study for citrus fruit packed in a single carton. Comput. Electron. Agric. 144, 199-208. https://doi.org/10.1016/ j.compag 201711.034

Xia, B., Sun, D.-W., 2002. Applications of computational fluid dynamics (cfd) in the food industry: a review. Comput. Electron. Agric. 34, 5-24. https://doi.org/ 10.1016/S0168-1699(01)00177-6.

Zhang, X., Lam, J.S.L., 2018. Shipping mode choice in cold chain from a value-based management perspective. Transp. Res. Part E Logist. Transp. Rev. 110, 147-167. https://doi.org/10.1016/j.tre.2017.11.015. 